Barker, P.F., Camerlenghi, A., Acton, G.D., and Ramsay, A.T.S. (Eds.)

Proceedings of the Ocean Drilling Program, Scientific Results Volume 178

\title{
8. Distribution of Clay Minerals In DRIFT Sediments ON THE Continental Rise West of the Antarctic Peninsula, ODP LEG 178, SITES 1095 AND $1096{ }^{1}$
}

\author{
Claus-Dieter Hillenbrand ${ }^{2}$ and Werner Ehrmann ${ }^{3}$
}

\begin{abstract}
The clay mineral compositions of upper Miocene to Quaternary sediments recovered at Ocean Drilling Program (ODP) Leg 178, Sites 1095 and 1096, from the continental rise west of the Antarctic Peninsula were analyzed in order to reconstruct the Neogene and Quaternary Antarctic paleoclimate and ice dynamics. The clay mineral assemblages are dominated by smectite, illite, and chlorite. Kaolinite occurs only in trace amounts. Analysis of a surface-sample data set facilitates the assignment of these clay minerals to particular source areas on the Antarctic Peninsula and, thus, the reconstruction of transport pathways. In the ODP cores, clay mineral composition cyclically alternates between two end-member assemblages. One assemblage is characterized by $<20 \%$ smectite and $>40 \%$ chlorite. The other assemblage has $>20 \%$ smectite and $<40 \%$ chlorite. Illite fluctuates between $30 \%$ and $50 \%$ without a significant affinity to one end-member assemblage. By comparison with a Quaternary sediment sequence from gravity core PS1565, the clay mineral fluctuations can be ascribed to glacial and interglacial periods, respectively. The cyclic changes in the clay mineral composition suggest that glacial-interglacial cycles, repeated ice advances and retreats, and changes in the Antarctic ice volume were already a main control of the global climate in late Miocene time. Throughout the late Neogene and Quaternary, the clay mineral records in the drift sediments exhibit only slight long-term changes predominantly attributed to local changes in glacial erosion and supply of
\end{abstract}

${ }^{1}$ Hillenbrand, C.-D., and Ehrmann, W., 2001. Distribution of clay minerals in drift sediments on the continental rise west of the Antarctic Peninsula, ODP Leg 178, Sites 1095 and 1096. In Barker, P.F., Camerlenghi, A., Acton, G.D., and Ramsay, A.T.S. (Eds.), Proc. ODP, Sci. Results, 178, 1-29 [Online]. Available from World Wide Web: $<$ http://www-odp.tamu.edu/ publications/178_SR/VOLUME/ CHAPTERS/SR178_08.PDF>. [Cited YYYY-MM-DD]

${ }^{2}$ Alfred Wegener Institute for Polar and Marine Research, PO Box 120161, D-27515 Bremerhaven, Federal Republic of Germany.

chillenbrand@awi-bremerhaven.de ${ }^{3}$ University of Leipzig, Institute for Geophysics and Geology, Talstrasse 35, D-04103 Leipzig, Federal Republic of Germany.

Initial receipt: 17 October 2000 Acceptance: 3 April 2001

Web publication: 2 July 2001

Ms 178SR-224 
source rocks. The absence of clear long-term trends associated with major climatic or glaciological changes points to an onset of vast glaciation in the Antarctic Peninsula region before $\sim 9 \mathrm{Ma}$ and to relative stability of the Antarctic ice sheet since then.

\section{INTRODUCTION}

\section{Scientific Objectives}

The recent Antarctic ice sheet plays an important role in the global climate system by influencing the atmospheric and oceanic circulation of our planet (e.g., Barker et al., 1998). Very little, however, is known about the development of the Neogene Antarctic ice sheet and its impact on the environment. Until now, the Neogene glacial and climatic history of Antarctica has been deduced mainly from proxy data obtained at low latitudes, such as oxygen isotopes, which were measured on benthic foraminifers recovered from well-dated and complete marine sedimentary sequences in the pelagic sea. However, the isotope data are ambiguous because they record both the volume of the ice sheets and the temperature of seawater (e.g., Abreu and Anderson, 1998; Barker et al., 1999).

The behavior of the Cenozoic Antarctic ice sheet can best be studied from sediments drilled in proximal glaciomarine settings, because there, direct evidence exists for ice advances and retreats through time. Such settings have been drilled in Prydz Bay and in the Ross Sea. However, core recovery on the Prydz Bay shelf was very poor (Barron, Larsen, et al., 1989; Hambrey et al., 1991). Much better core recovery was achieved by drilling on the continental shelf of McMurdo Sound in the Ross Sea. Cores CIROS-1, CIROS-2, and MSSTS-1 recovered upper Eocene to Quaternary sediments there (Barrett and Scientific Staff, 1985; Barrett, 1986, 1989). More recent drilling off Cape Roberts in McMurdo Sound also recovered upper Eocene to Quaternary sediments (Cape Roberts Science Team, 1998, 1999, 2000). However, dating was problematic for all cores from the shelf areas, and all proximal sequences show evidence for long and repeated hiatuses.

The main objectives of Ocean Drilling Program (ODP) Leg 178 were to recover and investigate complete high-resolution Neogene to Quaternary sedimentary sequences at the Antarctic continental margin and, based on these studies, to reconstruct the evolution of the Antarctic ice sheet and its influence on the global climate system over the past $\sim 10$ m.y. The target area was the Bellingshausen Sea, west of the Antarctic Peninsula (Fig. F1). This paper contributes to the understanding of the glacial and climatic history by focusing on the clay mineral assemblages in sediments recovered at ODP Sites 1095 and 1096 (Fig. F1). We use the clay minerals to reconstruct the provenance and transport paths of the sediments in response to glacial dynamics in the Antarctic Peninsula region during both the present and late Neogene to Quaternary times.

The clay mineral types and proportions of the individual clay minerals in marine sediments strongly depend on the climatic conditions on land and on the nature of the source rocks. Therefore, clay minerals are predestined to be indicators of modifications in the environment and contribute to the reconstruction of the climatic history as well as of sedimentary processes (e.g., Chamley, 1989; Weaver, 1989). Clay minerals in sediments from the Southern Ocean are predominantly of detrital origin (e.g., Piper and Pe, 1977; Barker, Kennett, et al., 1988; Setti et al.,
F1. Bathymetric map of the continental margin west of the Antarctic Peninsula, p. 22.

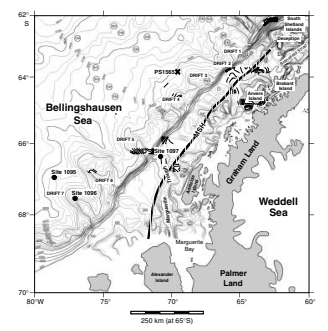




\section{C.-D. Hillenbrand AND W. Ehrmann

1997, 1998). Recent studies of sediment cores from the Antarctic continental margin have demonstrated the value of clay mineral assemblages for deciphering sediment provenance (e.g., Ehrmann et al., 1992; Petschick et al., 1996; Ehrmann, 1998a, 1998b, in press). Within the Antarctic Ocean, clay mineral assemblages also are good tracers for reconstructing the paleoceanography during Neogene and Quaternary times (e.g., Robert and Maillot, 1990; Hambrey et al., 1991; Ehrmann and Mackensen, 1992; Ehrmann et al., 1992; Diekmann et al., 1996; Ehrmann, 1998a).

\section{Regional Setting}

The Leg 178 sites were drilled along the continental margin in the Bellingshausen Sea. This marginal sea in the Pacific sector of the Southern Ocean is located between $60^{\circ} \mathrm{W}$ and $100^{\circ} \mathrm{W}$ and is bounded to the southeast by the Antarctic Peninsula (Fig. F1). Graham Land and Palmer Land, which constitute the mainland of the Antarctic Peninsula, are covered with an ice sheet of variable thickness, whereas the islands west of the Antarctic Peninsula carry local ice caps. The ice drains through valley glaciers and ice streams flowing perpendicular to the Antarctic Peninsula axis and away from the islands' highlands, respectively. The glaciers and ice streams terminate at the coasts as floating glacier tongues, ice cliffs, or small ice shelves (Keys, 1990). Icebergs calved into the Bellingshausen Sea drift with coastal currents across the shelf and slope before they are transferred into the clockwise-flowing Antarctic Circumpolar Current (ACC). The continental shelf west of the Antarctic Peninsula is up to $150 \mathrm{~km}$ wide (Fig. F1) and exhibits the typical Antarctic shelf morphology characterized by general landward sloping and overdeepening to an average water depth of $450 \mathrm{~m}$. The shelf can be divided into three physiographic provinces: a mostly shallow inner-shelf province at $\sim 200 \mathrm{~m}$ water depth, a mostly sediment-buried "mid-shelf high" (Fig. F1), and an extensive prograded outer shelf (Larter and Barker, 1989; Pudsey et al., 1994; Larter et al., 1997; Rebesco et al., 1998). Progradation is focused in discrete depositional centers ("lobes"). Broad troughs, like Marguerite Trough (Fig. F1), cross the inner shelf and the mid-shelf high and terminate between the lobes. The troughs are supposed to represent the paleo-pathways of thick, grounded ice streams (Pope and Anderson, 1992; Pudsey et al., 1994; Rebesco et al., 1998). The genesis and morphology of the shelf structures are explained by a complex interaction of climatically induced erosion and sedimentation processes with isostatic and tectonic subsidence during Neogene and Quaternary times (Larter and Barker, 1991; Larter et al., 1997; Rebesco et al., 1998).

The upper continental slope is very steep beyond the lobes (up to $17^{\circ}$ ) but more gentle beyond the glacial trough mouths (Vanneste and Larter, 1995; Rebesco et al., 1998). The lower slope is smooth (Larter and Cunningham, 1993). Dendritic tributary gullies, up to $1 \mathrm{~km}$ wide and $75 \mathrm{~m}$ deep, start at the foot of the slope below the lobes and converge into up to 5-km-wide and 150-m-deep meandering channels (Tomlinson et al., 1992; Rebesco et al., 1998). These deeply incised main channels are oriented perpendicular to the continental slope and cross the continental rise towards the Bellingshausen abyssal plain. On the upper continental rise, they flow around nine mound-shaped sediment bodies interpreted as asymmetric drifts (Fig. F1) (Rebesco et al., $1996,1997,1998)$. The drifts are $100-300 \mathrm{~km}$ long, 50-100 km wide, and have an elevation of up to $900 \mathrm{~m}$ above the seafloor. Sediment 


\section{C.-D. Hillenbrand AND W. Ehrmann

waves, dunes, and levees associated with the main channels were reported from the lower continental rise (Tucholke, 1977). Deep-sea fans with abyssal hills along their northern boundary cover the Bellingshausen abyssal plain (Vanney and Johnson, 1976; Tucholke, 1977; Wright et al., 1983; Anderson, 1990).

Sites 1095 and 1096 are located just within the Antarctic Zone of the Southern Ocean. The Antarctic Zone is bounded by the Polar Front in the north and by the southern boundary of the ACC in the south (Orsi et al., 1995). Because of seasonal sea ice coverage, open-water conditions prevail for only $\sim 3$ mo during spring and summer at Sites 1095 and 1096 (Parkinson, 1994). Warm Circumpolar Deep Water (CDW) upwells in the Bellingshausen Sea near the continental slope of the Antarctic Peninsula and intrudes onto the shelf underneath Antarctic Surface Water (AASW) (Talbot, 1988; Hofmann et al., 1996).

The circulation pattern on the shelf west of the Antarctic Peninsula is quite complex, with surface currents mainly toward the southwest. Hofmann et al. (1996) and Smith et al. (1999) assume the existence of weak cyclonic gyres located in the Bransfield Strait, off Anvers Island, and north of Marguerite Bay. A slow southwest current adjacent to the coast of the Antarctic Peninsula and a northeast countercurrent farther offshore are associated with these gyres. Northwest of the South Shetland Islands, information regarding surface- and deep-water circulation along the continental slope and rise is contradictory. Stationary hydrographic data by Orsi et al. (1995) suggest southwestward flow only extending from the shelf edge down to $\sim 2400 \mathrm{~m}$ water depth, whereas current measurements by Nowlin and Zenk (1988) indicate persistently southwestward near-bottom flow along the continental margin down to $\sim 4000 \mathrm{~m}$ water depth. No evidence for a slope current was found west of $\sim 63^{\circ} \mathrm{W}$ (Hofmann et al., 1996; Whitworth III et al., 1998).

On the flanks of Drift 7 near Sites 1095 and 1096, Camerlenghi et al. (1997) detected a weak bottom-water flow over the upper continental rise using two moored current meters. The measured current speed $8 \mathrm{~m}$ above the seabed was an average of $6.2 \mathrm{~cm} / \mathrm{s}$ and never exceeded $20 \mathrm{~cm} /$ $\mathrm{s}$ during the 10-mo measuring period. The direction of bottom-water flow followed the bathymetric contours. Thus, the bottom current was directed to the west at the drift's gentle northeastern side and toward the continental slope at its southwestern flank. The potential temperature of the bottom water is comparable to deep-water temperatures measured at the South Shetland margin. The bottom water in this area is derived from Weddell Sea Deep Water (WSDW), which leaves the Weddell Sea through topographic gaps in the Scotia Ridge (Nowlin and Zenk, 1988).

\section{Geological Setting}

The Antarctic Peninsula predominantly consists of calc-alkaline plutonic and volcanic rocks of a deeply eroded magmatic arc belonging to the Andean Orogen. The magmatic arc formed from Late Jurassic to late Tertiary as a result of the subduction of proto-Pacific oceanic lithosphere beneath the continental margin of Gondwana (Thomson et al., 1983; Davey, 1990; Elliot, 1997). Along the Pacific side of the Antarctic Peninsula, subduction ceased progressively northeastward with time, as offset sections of spreading centers collided with the trench (e.g., Larter and Barker, 1991; Larter et al., 1997).

Magmatic activity associated with the Andean Orogeny started during the middle Triassic with vast intrusions of felsic to mafic plutonic 
rocks ("Antarctic Peninsula Batholith") and continued until the Neogene. Thereby, centers of magmatic activity shifted both to the north and in a westerly direction (Thomson and Pankhurst, 1983; Pirrie, 1991). Calc-alkaline volcanic rocks ("Antarctic Peninsula Volcanic Group") were extruded from the middle Jurassic to the Pliocene (Thomson and Pankhurst, 1983; Smellie, 1990). Miocene to Holocene volcanism concentrated on offshore islands west of the Antarctic Peninsula as well as east of northern Graham Land, thereby exhibiting alkaline affinities (Elliot, 1997; Smellie, 1999). Still-active volcanism occurs in the area of the South Shetland Islands in response to the slow subduction of Pacific lithosphere beneath the northern Antarctic Peninsula at the South Shetland Trench and to the extension-related opening of the Bransfield Strait as a backarc basin (Davey, 1990; Elliot, 1997; Smellie, 1999).

The Andean Orogeny led to the development of a Jurassic to Cretaceous accretionary complex exposed on Alexander Island (Macdonald and Butterworth, 1990). Mesozoic forearc basins, which developed on the Pacific flank of the Antarctic Peninsula, are exposed on several islands adjacent to Graham Land (Macdonald and Butterworth, 1990; Elliot, 1997). Forearc basin strata are also assumed to constitute much of the shelf (Larter et al., 1997). Middle Jurassic to Eocene backarc basins formed in eastern Palmer Land and on islands east of Graham Land (Macdonald and Butterworth, 1990; Pirrie, 1991; Elliot, 1997). The forearc and backarc basins were mainly filled with thick clastic and volcanogenic marine to terrestrial sequences, which predominantly contain debris supplied from the magmatic arc rocks.

The pre-Jurassic basement of the magmatic arc includes deformed metasedimentary and crystalline rocks of an older Paleozoic to Triassic consuming plate margin (Thomson and Pankhurst, 1983; Elliot, 1997; Loske et al., 1998). The basement comprises upper Paleozoic to lower Mesozoic very low grade to greenschist facies sandstones and shales that are mainly exposed in northern Graham Land. Lower Paleozoic granitoids and gneisses, which were affected by late Paleozoic/early Mesozoic amphibolite facies metamorphic events, occur in scattered outcrops in southern Graham Land and Palmer Land (Elliot, 1997; Loske et al., 1998).

\section{MATERIALS AND METHODS}

\section{Core Material and Sampling}

During Leg 178, an almost complete upper Miocene to Quaternary sedimentary sequence with a thickness of $554 \mathrm{~m}$ was recovered at Site 1095 on the distal flank of Drift 7. A complete and high-resolution lower Pliocene to Quaternary sequence with a thickness of $673 \mathrm{~m}$ was recovered at Site 1096 near the crest of this drift (Fig. F1; Table T1). At both sites, the recovered sediments generally consist of thin-bedded, bioturbated to massive, diatom-bearing muds alternating with thickbedded, terrigenous, mainly fine-grained laminites (Barker, Camerlenghi, Acton, et al., 1999). The intervals with higher biogenic contents were interpreted as hemipelagic sediments deposited during interglacial periods, whereas the laminites were interpreted as distal turbidites and contourites deposited during glacial periods (Barker, Camerlenghi, Acton, et al., 1999). At distal Site 1095, turbidites are more abundant than at drift-crest Site 1096. The presence of ice-rafted debris (IRD) through-
T1. Location, water depth, and core recovery, Sites 1095, 1096, and 1097, p. 29. 
out the Neogene and Quaternary sediments indicates that they were deposited in a glaciomarine environment.

At Sites 1095 and 1096, multiple holes offset in depth were drilled to ensure recovery of a continuous sedimentary sequence (Table T1). All depth information (in meters below sea floor [mbsf]) given for the holes drilled at Sites 1095 and 1096 were recovery corrected and converted to meters composite depth (mcd) using the splices given by Barker, Camerlenghi, Acton, et al. (1999). We note that use of the revised composite depths given for Sites 1095 and 1096 by Barker (Chap. 6, this volume) does not influence our results significantly. Clay mineral assemblages were analyzed on 192 samples from Site 1095 and 119 samples from Site 1096 (Table T1), yielding an average sampling interval of $2.5 \mathrm{~m}$ for Site 1095 and $5.0 \mathrm{~m}$ for Site 1096. Corresponding average temporal resolutions of our sample sets are 48 k.y for Site 1095 and 39 k.y for Site 1096. We also analyzed 20 samples from Site 1097 in Marguerite Trough, from which a spot-cored Pliocene sequence of diamictons and glaciomarine muds was recovered (Fig. F1; Table T1) (Barker, Camerlenghi, Acton, et al., 1999).

For characterization of regional clay mineral distribution patterns in surface sediments west of the Antarctic Peninsula, we used published data from Petschick et al. (1996) and Diekmann et al. (2000). Clay mineral data from gravity core PS1565, located at the seaward termination of Drift 3 (Fig. F1), are presented to characterize changes in clay mineral assemblages during the last climatic cycle. These data have previously been published by Hillenbrand (2000).

All raw data presented in this study are available from the PANGAEA data bank of the Alfred Wegener Institute for Polar and Marine Research, Bremerhaven, Germany (http://www.pangaea.de).

\section{Analytical Procedure}

Sample preparation and clay mineral analyses followed methods given in Ehrmann et al. (1992) and Petschick et al. (1996). Bulk-sediment samples were oxidized and disaggregated by means of a $3 \%-10 \%$ $\mathrm{H}_{2} \mathrm{O}_{2}$ solution. After sieving the samples through a 2-mm and a $63-\mu \mathrm{m}$ mesh, the clay fraction $(<2 \mu \mathrm{m})$ was separated from the silt fraction in settling tubes (settling time based on Stokes' Law). Dried gravel, sand, silt, and clay fractions were weighed, and then the relative proportion of the clay fraction was calculated. Clay $(40 \mathrm{mg}$ ) was dispersed in an ultrasonic bath and mixed with $1 \mathrm{~mL}$ of an internal standard consisting of a $1 \% \mathrm{MoS}_{2}$ suspension. The samples were mounted as texturally oriented aggregates by rapidly filtering the suspension through a membrane filter of $0.15-\mu \mathrm{m}$ pore width. The filter cakes were dried at $60^{\circ} \mathrm{C}$ and mounted on aluminum tiles. They were exposed to ethylene glycol vapor at a temperature of $60^{\circ} \mathrm{C}$ for $\sim 18 \mathrm{hr}$ immediately before the X-ray analyses. The measurements were conducted on an automated powder diffractometer system Philips PW1700 with $\mathrm{CoK}_{\alpha}$ radiation $(40 \mathrm{kV}, 40$ $\mathrm{mA}$ ). The samples were $X$-rayed in the range $2^{\circ}-40^{\circ} 2 \theta$ with a scan speed of $0.02^{\circ} 2 \theta / \mathrm{s}$. Additionally, the range $28^{\circ}-30.5^{\circ} 2 \theta$ was measured with a step size of $0.005^{\circ} 2 \theta$ in order to better resolve the (002) kaolinite peak and the (004) chlorite peak. The X-ray diffractograms were evaluated on an Apple Macintosh personal computer using the "MacDiff" (version 4.0.5) software (freeware available from http://servermac.geologie.uni-frankfurt.de/HomePage.html). 


\section{C.-D. Hillenbrand AND W. Ehrmann

This study concentrates on the main clay mineral groups smectite, illite, chlorite, and kaolinite. These clay minerals were identified by their basal reflections at $\sim 17 \AA$ (smectite), 10 and $5 \AA$ (illite), 14.2, 7, 4.72, and $3.54 \AA$ (chlorite), and 7 and $3.57 \AA$ (kaolinite). Semiquantitative evaluations of the mineral assemblages were made on the integrated peak areas. The relative percentages of smectite, illite, chlorite, and kaolinite were determined using empirically estimated weighting factors (Biscaye, 1964, 1965; Brindley and Brown, 1980). No effort was made to quantify mixed-layer clay minerals.

\section{Stratigraphy}

Age models for Sites 1095 and 1096 are based on the magnetostratigraphic datums published in Barker, Camerlenghi, Acton, et al. (1999) using the timescale and polarity history nomenclature of Berggren et al. (1995). Ages for the individual samples were calculated by linear interpolation between the datum levels. Computed linear sedimentation rates slightly differ from the sedimentation rates given by Barker, Camerlenghi, Acton, et al. (1999), because we refer the paleomagnetic ages to recovery-corrected composite depths. The age model for Site 1096 was refined by including the Reunion Event (Chron 2r.1n), which was identified in Core 178-1096C-2H (G. Acton, pers. comm., 1999). At Site 1095, we considered a hiatus within the upper Pliocene sedimentary sequence as suggested in Barker, Camerlenghi, Acton, et al. (1999). The shipboard paleomagnetic data indicate that this hiatus spans the earliest Matuyama Chron (C2r) and the onset of the Olduvai Event (C2n). Assuming nondeposition or erosion for the corresponding time period between 2.581 and $1.770 \mathrm{k} . y$. , we calculated a linear sedimentation rate of $5.0 \mathrm{~cm} / \mathrm{k} . \mathrm{y}$. for the late Gauss Chron (C2An.1n). This value agrees well with the sedimentation rate of $4.8 \mathrm{~cm} / \mathrm{k} . \mathrm{y}$. calculated for the sediments deposited during the late Matuyama Chron.

\section{RESULTS}

\section{Sites 1095 and 1096}

All results are plotted against depth in Figures F2 and F3. The clay fraction $(<2 \mu \mathrm{m})$ at Sites 1095 and 1096 in general varies between 30 and $60 \mathrm{wt} \%$. Only a few samples taken from coarser-grained turbidites have lower clay contents. The predominantly muddy grain size of the investigated sediments is shown by Pudsey (submitted a, submitted b, this volume), who used a silt/clay boundary at $4 \mu \mathrm{m}$.

The clay mineral assemblages are dominated by smectite, illite, and chlorite. Kaolinite occurs in minor concentrations $(<5 \%)$, and its distribution is therefore not shown in Figures F2 and F3. At both sites, the smectite concentration is highly variable, with values between $0 \%$ and $50 \%$. Illite fluctuates much less; concentrations are mainly $30 \%$ to $45 \%$ at Site 1095 and $30 \%$ to $55 \%$ at Site 1096 . Chlorite concentrations are $20 \%$ to $60 \%$ at both sites. Other minerals detected in the clay mineral fraction are quartz, plagioclase feldspar, K-feldspar, and amphibole.
F2. Distribution of smectite, illite, and chlorite, Site 1095, p. 23.

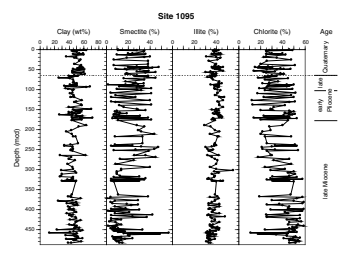

F3. Distribution of smectite, illite, and chlorite, Site 1096, p. 24.

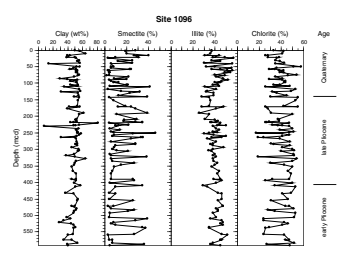




\section{Site 1097 and Regional Clay Mineral Assemblages in Surface Sediments}

At Site 1097, smectite varies from $3 \%$ to $27 \%$, illite from $31 \%$ to $41 \%$, and chlorite from $41 \%$ to $63 \%$. The fluctuations of clay minerals are independent of the lithologies. Because of the very poor core recovery at Site 1097 and the limited number of samples, only the average clay mineral composition in combination with the regional clay mineral distribution in the surface sediments is presented (Fig. F4).

\section{DISCUSSION}

\section{Provenance of Clay Mineral Assemblages}

A prerequisite for the reconstruction of transport pathways is the identification of specific source areas on the Antarctic Peninsula and the adjacent islands. However, the heterogenous petrology of magmatic arc rocks and associated units as well as the extensive ice cover make this identification difficult. The investigation of the clay mineral distribution in surface sediments of the Atlantic sector of the Southern Ocean reveals important clues for mapping specific clay mineralogical source areas. Clays supplied by the rocks exposed on the Antarctic Peninsula represent a significant source for chlorite and smectite, which are transported to the shelf break by surface currents and glaciomarine processes. There, chlorite and smectite are injected into the eastward-flowing ACC and then exported to the Atlantic sector (Petschick et al., 1996; Diekmann et al., 1996).

\section{Continental Shelf}

A detailed analysis of the clay mineralogical assemblages deposited on the shelf northwest of the Antarctic Peninsula reveals a varied pattern of clay mineralogical provenance. Smectite concentrations are highest ( $>60 \%$ ) in surface sediments in the far northeast (Fig. F4). This area is referred to as the "smectite province." Detrital and/or authigenic smectite is probably supplied by Mesozoic volcanic arc rocks and by associated volcano-sedimentary forearc basin strata exposed in Graham Land, on the adjacent islands, and possibly within the shelf (Pirrie, 1991; Petschick et al., 1996). Because these rock units, however, occur along the whole axis of the Antarctic Peninsula, the smectite maximum off northern Graham Land requires an additional source.

Potential further sources are the Cenozoic volcanic, pyroclastic, and volcaniclastic deposits outcropping mainly on the South Shetland Islands, Brabant Island, and Anvers Island (Petschick et al., 1996; Hillenbrand, 2000). This is supported by a smectite content of $95 \%$ in sediments near the active volcano on Deception Island (Fig. F4). In the South Shetland Islands area, submarine weathering of Cenozoic tephra and volcanic rocks producing smectite may play an important role (Petschick et al., 1996). Furthermore, some of the alkaline volcanics exposed in northern Graham Land and on the adjacent islands were extruded subglacially (e.g., Smellie and Skilling, 1994). This process is known to represent a very effective mechanism for smectite formation. In contrast, authigenic smectite found in volcanogenic soils on the South Shetlands was shown to be produced by hydrothermal alteration rather than by chemical weathering (Blümel et al., 1985). Therefore,
F4. Clay mineral assemblages, p. 25.

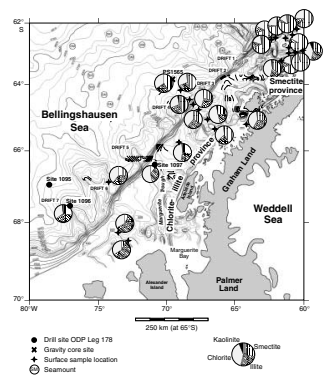




\section{C.-D. Hillenbrand AND W. Ehrmann

soils in the South Shetland Islands area only represent a secondary source for smectite.

We consider that the highest smectite concentrations within the smectite province are probably restricted to the shelf northwest and southwest of the South Shetland Islands, as indicated by clay mineral studies of Shuitu (1990). Surface sediments taken from the inner parts of the Bransfield Strait, in contrast, contain more illite and chlorite (Shuitu, 1990; Yoon et al., 1992). Two samples in the smectite province are characterized by relatively low smectite but higher chlorite concentrations (Fig. F4). These samples were taken from the deeper Bransfield Basin, below $850 \mathrm{~m}$ water depth. An increase in chlorite near Smith Island was reported by Yoon et al. (1992), who assume chlorite supply from Paleozoic metamorphic rocks exposed on that island. We speculate that detrital supply from similar basement rocks known to crop out on the steep margins of deep basins within the Bransfield Strait (Jeffers and Anderson, 1990) cause the relative chlorite increase observed in our samples.

The shelf sediments south of $64^{\circ} \mathrm{S}$ contain less smectite and more chlorite and illite, forming a "chlorite-illite province" (Fig. F4). Whereas chlorite is the most abundant clay mineral offshore southern Graham Land, illite is dominant northwest of Alexander Island. Chlorite and illite are predominantly supplied by physical weathering under the polar climatic conditions of basement metamorphics and igneous rocks of the Andean Orogen. Altered calc-alkaline volcanics might represent the most important source for chlorite, as indicated by petrographic analyses (West, 1974; Hoecker and Amstutz, 1987). Lower smectite concentrations in the chlorite-illite province with respect to the smectite province possibly point to the rare occurrences of Cenozoic volcanics in the southern Antarctic Peninsula area.

Within the chlorite-illite province, illite concentration increases toward the southwest but only two surface sediment samples were investigated from the shelf northwest of Alexander Island. Both have illite contents around $60 \%$. Together with illite derived from gneissic rocks, which are widespread in northern Palmer Land (Davies, 1984; Smith, 1987), considerable amounts of illite may be supplied from a Tertiary batholith exposed in the Rouen Mountains at the northern tip of Alexander Island (Care, 1983). This suggestion is confirmed by nearby recovered basal tills, which are virtually monolithologic and comprise quartz-mica schistose/gneissic pebbles interpreted to be derived from the Rouen Mountains (Kennedy and Anderson, 1989). Therefore, we speculate that the illite dominance in the shelf sediments northwest of Alexander Island might represent a restricted local signal.

Unfortunately, no clay mineral data for surface sediments from the Marguerite Bay area were available. To get an idea of the representative clay mineral assemblages of this shelf region, we investigated samples from ODP Site 1097 located at the northern end of Marguerite Trough (Figs. F1, F4). Marguerite Trough was eroded by ice streams, which had advanced from Marguerite Bay northward during glacial periods, draining both northern Palmer Land and eastern Alexander Island (e.g., Pope and Anderson, 1992). The mean clay mineral assemblage of 20 samples from Site 1097 consists of 54\% chlorite and 36\% illite, indicating that the bedrock in northern Palmer Land/eastern Alexander Island represents a source for detritus enriched in these clay minerals. Nevertheless, illite content at Site 1097 is generally higher than in the northern part of the chlorite-illite province. The higher illite concentrations are probably supplied by the gneissic rocks exposed in northern Palmer Land. 


\section{Continental Rise}

The clay mineral assemblages in surface sediments on the continental rise offshore from the chlorite-illite province exhibit a clear enrichment in smectite (Fig. F4). At present, glaciogenic detritus derived from the Antarctic Peninsula and the adjacent islands is released into the sea near the coast and transported farther offshore by tidal and winddriven circulation (e.g., Domack and Ishman, 1993; Ashley and Smith, 2000). We consider terrigenous particles released in the Bransfield Strait not relevant to sedimentation on the slope and rise because they are probably carried to the northeast by a cyclonic current located within the strait (Hofmann et al., 1996). Fine-grained components of the glaciogenic detritus derived from the northwestern coasts of the South Shetlands as well as from the coasts in the chlorite-illite province, however, may travel across the shelf driven by currents. Thereby, circulation patterns on the shelf suggest meandering rather than straight transport pathways to the shelf edge (Smith et al., 1999).

We expect clay-sized particles settling down through the water column above the slope and rise offshore from the smectite province to be transported southwestward by the current regime measured there (Nowlin and Zenk, 1988). In contrast, fine-grained particles settling down above the continental slope west of $63^{\circ} \mathrm{W}$, including those derived from the chlorite-illite province, may be deposited more or less in situ because of the lack of along-slope currents (Whitworth III et al., 1998). Offshore from Graham Land, intense erosional features reported from the $16^{\circ}$ steep upper continental slope by Vanneste and Larter (1995) may point to a still-recent activity of turbidity currents there. We assume, however, that the possible supply of terrigenous detritus to the rise by turbidity currents only plays a minor role at present.

Bottom-current regime on the upper continental rise is dominated by general southwestward flow in the whole study area (Nowlin and Zenk, 1988; Camerlenghi et al., 1997). Therefore, fine-grained particles settling down to the upper rise offshore from the smectite province and from the chlorite-illite province are entrained into this bottom current. We expect at least some of the particles to be transported farther to the southwest before deposition. Consequently, the clay mineral assemblage in the rise sediments offshore from the chlorite-illite province comprises higher amounts of smectite, which was injected into the bottom current at the continental rise offshore from the smectite province (Hillenbrand, 2000; Pudsey, 2000).

\section{Glacial-Interglacial Cyclicity of Clay Mineral Assemblages during the Late Quaternary}

Late Quaternary variations of clay mineral assemblages deposited at the Antarctic Peninsula's continental rise show a remarkable glacialinterglacial cyclicity with enhanced smectite concentrations during interglacial periods and high chlorite contents during glacials (Hillenbrand, 2000). At gravity core site PS1565, which is located offshore from the chlorite-illite province (Fig. F4), these variations are depicted for the last $130 \mathrm{k} . y$. (Fig. F5). Smectite contents increase at the transition between oxygen isotope Stages 6 and 5, are high during the early as well as late Stage 5, and decrease during Stages 4-2. Smectite increases again at the transition between Stages 2 and 1. Chlorite concentrations mirror the smectite variations inversely, thereby reaching maximum values during the late period of Stages $4-2$, which possibly

F5. Clay and clay mineral contents, core PS1565, p. 26.

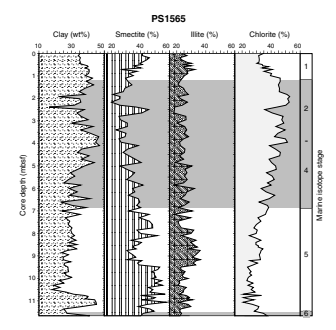


represents the last glacial maximum. In contrast to the variations of smectite and chlorite, no clear correlation of the illite content with global climatic cycles is visible. The observed cyclicity in smectite-chlorite fluctuations seems representative for the whole continental rise area between Drifts 3 and 5 (Pudsey, 2000).

During interglacial periods, smectite is delivered from the smectite province to site PS1565 by bottom-current transport along the continental rise. The decrease of smectite during glacial periods may be explained by two different mechanisms. The first is a consequence of previously suggested climate-induced changes in depositional processes on the margin (e.g., Pudsey and Camerlenghi, 1998; Rebesco et al., 1998; Hillenbrand, 2000; Pudsey, 2000). During glacial periods, grounded ice streams advanced across the shelf of the chlorite-illite province, eroded predominantly chlorite-rich detritus, and transported the debris seaward. The supply of eroded detritus to the outer shelf and the shelf edge increased, particularly during glacial maxima, when grounded ice streams had reached the shelf break. Rapid accumulation of unsorted debris near the shelf edge caused gravitational instabilities. These instabilities triggered slumps and slides on the upper slope, which turned into turbidity currents at the base of the slope. The turbidity currents cut channels into the upper continental rise and transported most terrigenous detritus down to the lower rise and to the Bellingshausen abyssal plain. Fine-grained particles within the suspension cloud of the turbidity currents, however, were captured by the southwestward-flowing bottom current and were deposited at the drifts as well as in the adjacent rise areas. Consequently, the higher input of detritus derived from the chlorite-illite province into the bottom current during glacial periods resulted in a higher proportion of chlorite within the clay mineral assemblage deposited at site PS1565. During the glacial-interglacial transitions, grounded ice streams retreated and thus the supply of chlorite-enriched debris to the slope and rise decreased.

On the other hand, a weakening of bottom-current intensity during glacial periods might have restricted the supply of smectite-rich detritus to the continental rise off southern Graham Land. The hypothesis of a glacial reduction in bottom-current strength may be supported by reconstructions of paleo-grounding lines in the Weddell Sea, indicating that no large ice shelves existed there during glacial maxima. Instead, grounded ice had advanced at least to the outer shelf (e.g., Bentley and Anderson, 1998). At the present time, dense bottom-water masses in the Weddell Sea, which crucially contribute to the production of Weddell Sea Deep Water (WSDW) via mixing processes, are derived from super-cooled shelf waters forming beneath the large ice shelves (e.g., Orsi et al., 1993). Widely grounded ice on the Weddell Sea shelf during glacial times would have limited the formation of WSDW and weakened bottom-water flow on the continental rise west of the Antarctic Peninsula. Any glacial reduction of bottom-water flow should not only have reduced southwestward transport of smectite but also should have caused a significant increase in deposition of clay-sized particles.

In core PS1565, there is only a weak correlation between changes in clay contents and variations of chlorite (Fig. F5). In principle, the proportion of the clay fraction does not reflect glacial-interglacial cyclicity. More sophisticated grain-size analyses, which were carried out on the upper Quaternary sequences recovered at Sites 1095 and 1096 by Pudsey (submitted a, submitted b, this volume) show a slight decrease of the clay fraction during interglacials. This decrease, however, may at least be partly caused by an increase of silt-sized diatoms diluting the 
proportions of terrigenous clay. The diatoms were primarily supplied by vertical settling during interglacial times, independent of changes in bottom-current strength. Therefore, we suggest that glacial-interglacial cyclicity observed in the clay mineral assemblages deposited on the continental rise off southern Graham Land was predominantly controlled by changes in the supply of chlorite.

\section{Neogene to Quaternary Clay Mineral Assemblages in Sediments at Sites 1095 and 1096}

\section{Short-Term Variations}

According to the existing age model, the stratigraphic sequence of Site 1095 reaches back to $\sim 9.3 \mathrm{Ma}$ and that of Site 1096 to $\sim 4.7 \mathrm{Ma}$. Throughout these intervals, the clay mineral composition is characterized by major fluctuations of the individual clay minerals, particularly smectite and chlorite. The clay mineral assemblages alternate between two end-member assemblages (Figs. F6, F7). The first assemblage is characterized by smectite concentrations $<20 \%$ and chlorite concentrations $>40 \%$. The second assemblage has smectite concentrations $>20 \%$ and chlorite concentrations $<40 \%$. The illite concentrations in the sediments recovered at Sites 1095 and 1096 are generally higher than in gravity core PS1565 because the ODP sites are located offshore from the southern part of the chlorite-illite province where illite is more abundant (Fig. F4). As in core PS1565 sediments, the illite fluctuations cannot be easily correlated with fluctuations in the other clay minerals.

In general, a very similar pattern in the clay mineral distribution to that described in core PS1565 can be observed in the drill cores from Sites 1095 and 1096 if one takes into account the different sample spacing. The short-term cyclic changes in the clay mineral assemblages deposited at Sites 1095 and 1096 occur throughout the late Neogene and Quaternary (Fig. F6) independent of changes in the clay contents. The smectite-poor assemblages are interpreted to indicate more glacial conditions, whereas smectite-rich assemblages may indicate more interglacial conditions (Fig. F7). We suppose that the short-term fluctuations of clay mineral assemblages at Sites 1095 and 1096 were caused by the repeated advance and retreat of grounded ice masses across the shelf of the Antarctic Peninsula, resulting from changes of Antarctic ice volume.

Antarctic ice volume changes are thought to have influenced the oxygen isotope record in benthic foraminiferal tests on Milankovitch timescales since the early Pliocene (Shackleton, 1995; Barker et al., 1999). There is some debate, however, whether ice volume in Antarctica already fluctuated on orbital timescales during the late Miocene (Barker et al., 1999). For the time interval between 7 and $5 \mathrm{Ma}$, benthic $\delta^{18} \mathrm{O}$ fluctuations with the 41-k.y. period of orbital obliquity were reported both from Morocco (Hodell et al., 1994) and from the equatorial West Atlantic (Shackleton and Hall, 1997). Whereas those from Morocco were interpreted to be controlled, at least in part, by Antarctic ice volume changes (Hodell et al., 1994), those from the Atlantic were assumed to exclusively reflect changes in deep-water temperatures (Shackleton and Crowhurst, 1997).

The pronounced short-term fluctuations in the clay mineral record at Site 1095 strongly suggest that Antarctic ice volume changes already occurred during the late Miocene. This might support the interpretation of Hodell et al. (1994). We consider, however, that our sample set from Site 1095 yields too low a stratigraphic resolution for time-series analy-
F6. Variations in clay mineral composition, Sites 1095 and 1096, p. 27.

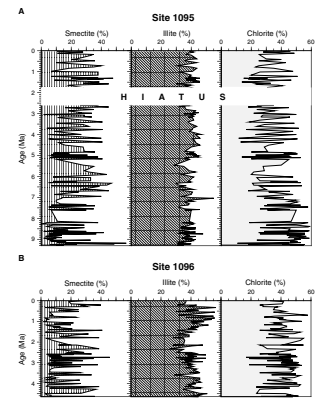

F7. Ternary plot of clay mineral composition, p. 28.

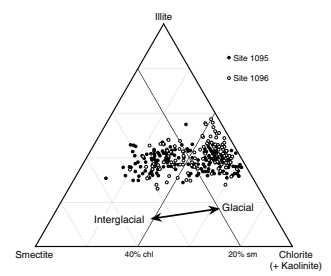


ses in the obliquity band. Moreover, the assumption of periodical expansion and contraction of the Antarctic Peninsula ice cap may imply that the Antarctic ice sheet had reached a size to make it sensitive to sea-level changes, which might have been internally generated (Barker et al., 1999).

\section{Long-Term Variations}

In contrast to other sedimentological parameters (e.g., the opal record) (Hillenbrand and Fütterer, submitted, this volume), we observe only weak long-term changes in the clay mineral assemblages deposited on the continental rise west of the Antarctic Peninsula. At Site 1095, smectite contents slightly increase at $\sim 7.0 \mathrm{Ma}$ and decrease at $\sim 5.4 \mathrm{Ma}$, fluctuating afterward around a higher mean value than before $7.0 \mathrm{Ma}$ (Fig. F6A). Chlorite variations reflect this pattern inversely. The increase of smectite roughly coincides with an intensification of Neogene volcanism in the northern Antarctic Peninsula region (Smellie, 1990), which ultimately may have resulted in a greater supply of smectite-enriched clay to Site 1095. A more pronounced intensification of volcanism in the northern Antarctic Peninsula region, however, took place during the Pliocene and Pleistocene (Smellie, 1990). Therefore, we conclude that it is improbable that intensified late Neogene volcanism in the smectite province represents the only cause for the slightly enhanced smectite concentrations between $\sim 7.0$ and $\sim 5.4 \mathrm{Ma}$.

Because grain-size distribution at Site 1095 gives no clear evidence for a significant change in paleobottom-current strength during the late Miocene (Pudsey, submitted a, this volume), we speculate that local changes in glacial erosion linked to tectonic processes have contributed to the increase of smectite at Site 1095. The occurence of redeposited neritic diatoms in the drift sediments at Site 1095 points to a shallowing of the Antarctic Peninsula's shelf between $\sim 7.8$ and $\sim 6.2 \mathrm{Ma}$ (M. Iwai, pers. comm., 1999). No global sea-level fall is known from that time interval (e.g., Abreu and Anderson, 1998). Therefore, the sea-level lowstand recorded at Site 1095 must have been a consequence of local uplift, which probably resulted in an intensification of glacial erosion in the corresponding hinterland. South of $64^{\circ} \mathrm{S}$, the Cenozoic subduction of oceanic crustal segments below the Pacific margin of the Antarctic Peninsula had ceased at $\sim 14.1 \mathrm{Ma}$, at the latest (Larter and Barker, 1991; Larter et al., 1997). Uplift related to the ridge crest-trench collision, which was concentrated on a relatively narrow zone on the shelf, lasted only for 1-4 m.y. (Larter and Barker, 1991; Larter et al., 1997). Thus, the chlorite-illite province should have been in subsidence since $10 \mathrm{Ma}$ and glacial erosion should have remained rather constant during the late Miocene.

In contrast, ridge-crest segments collided with the paleo-trench offshore from Anvers Island and Brabant Island from 11.2 to $3.3 \mathrm{Ma}$ and subduction in the South Shetland Trench may still continue recently (Larter and Barker, 1991; Larter et al., 1997). Most collision ages offshore from the southern part of the smectite province date at $~ 6.6 \mathrm{Ma}$. We assume that in the southern smectite province, uplift processes related to ridge crest-trench collision started already at $\sim 7.8 \mathrm{Ma}$, causing a local sea-level lowstand. As a further consequence, glacial erosion of uplifted smectite-bearing rocks intensified at 7.0 Ma. The strengthening of erosion resulted in an increased supply of detritus enriched in smectite to the continental rise, where bottom currents carried the fine-grained debris southwestward to Site 1095. Subsidence in the southern part of the 
smectite province started only $1 \mathrm{Ma}$ after the ridge crest-trench collision. At $\sim 6.2 \mathrm{Ma}$, continued subsidence and repeated advance of grounded ice masses during cold periods had deepened the shelf to a water depth in which benthic diatoms could not survive. Glacial erosion in the southern smectite province had weakened to the pre-uplift level at $5.4 \mathrm{Ma}$, but intensified volcanism in the northern Antarctic Peninsula region during the late Neogene produced more smectite, so that smectite supply to Site 1095 did not decrease to the mean value recorded before $7.0 \mathrm{Ma}$.

At Site 1096, illite contents slightly increase between $\sim 1.5$ and $\sim 0.2$ $\mathrm{Ma}$, whereas illite concentrations at Site 1095 remain rather constant (Fig. F6). This suggests that during most of the Quaternary, northern Alexander Island, which represents the direct hinterland of Drift 7, was a more important source for fine-grained detritus supplied to Site 1096 than northern Palmer Land/eastern Alexander Island. Indications for changing contributions of local source areas within the southern chlorite-illite province may be derived from reconstructions of paleo icestream pathways on the shelf. Rebesco et al. (1998) inferred ice flow in Marguerite Trough during glacial periods exclusively in a northerly direction, indicating that glacial detritus from northern Palmer Land/ eastern Alexander Island was predominantly supplied to the slope adjacent to Drift 5. Bentley and Anderson (1998), in contrast, concluded from grounding zone wedges, which they found on the shelf northwest of Alexander Island, that ice streams also had spread out from Marguerite Trough to the outer shelf and the shelf break adjacent to Drifts 6 and 7.

We suppose that throughout the late Neogene and Quaternary, glacial debris was delivered from the southern chlorite-illite province to the outer shelf and the shelf edge via the ice stream pathways suggested by Bentley and Anderson (1998). Between 1.5 and $~ 0.2 \mathrm{Ma}$, however, the ice streams passing northern Alexander Island may have reached the shelf break adjacent to Drift 7 more often. This assumption is supported by the relative age relationships between the grounding zone wedges found on the shelf. They indicate that grounded ice streams advanced to the outer shelf during the last glacial maximum, whereas they had reached the shelf edge during older glacial periods (Bentley and Anderson, 1998). Moreover, detailed grain-size data show silty layers to be more abundant at Site 1096 between $1.7 \mathrm{Ma}$ and $100 \mathrm{ka}$ (Pudsey, submitted $b$, this volume). These silty layers are interpreted as distal turbidites (Barker, Camerlenghi, Acton, et al., 1999), which were probably triggered by more frequent advances of grounded ice streams to the shelf break adjacent to Drift 7 . The increased activity of turbidity currents at the continenal margin should have enriched the bottom current on the rise with glacial debris enriched in illite. While the illiterich detritus was predominantly deposited at proximal Site 1096, the bottom current supplied more fine-grained detritus derived from the northern part of the chlorite-illite province to the distal Site 1095.

\section{Implications for Glacial History}

In the late Neogene to Quaternary variations of clay mineral assemblages at Sites 1095 and 1096, we do not recognize pronounced longterm changes caused by major glaciological or climatic changes. This strongly suggests that the onset of vast glaciation on the Antarctic Peninsula predates the late Miocene and that polar weathering conditions prevailed on the Antarctic Peninsula throughout the last 9 m.y. Our 


\section{C.-D. Hillenbrand AND W. Ehrmann

suggestion is supported by the occurrence of IRD in upper Miocene sediments from the Bellingshausen Sea recovered both at Site 1095 and Site 325, Deep Sea Drilling Project Leg 35 (Hollister, Craddock, et al., 1976) and by mineralogical and sedimentological evidence from continental margin deposits recovered in the Weddell Sea during ODP Leg 113 (Kennett and Barker, 1990). These findings also indicate that major cooling and glaciation had affected the Antarctic Peninsula region at least since the late Miocene. Geochemical investigations carried out on sedimentary rocks point to a prevalence of glacial climatic conditions on the Antarctic Peninsula even since the early Oligocene (Dingle and Lavelle, 1998). The buildup of large ice sheets in West Antarctica, including the Antarctic Peninsula ice cap, may have taken place at $\sim 15$ Ma and contributed to a major eustatic sea-level drop (Abreu and Anderson, 1998), which is known to be caused by a significant increase in global ice volume (Lear et al., 2000). The clay mineral records in the drift sediments on the Antarctic continental rise give no evidence for major deglaciation events during the late Neogene (e.g., Webb and Harwood, 1991), supporting the assumption that the Antarctic ice sheet as a whole had been quite stable since that time (Barker et al., 1999).

\section{CONCLUSIONS}

1. Clay mineral assemblages in surficial continental margin sediments west of the Antarctic Peninsula consist of smectite, chlorite, and illite, with kaolinite occurring only in trace amounts. High smectite concentrations typify the shelf sediments off northern Graham Land, whereas chlorite and illite dominate shelf deposits offshore from the southern Antarctic Peninsula. At the continental rise, a bottom current transports smectite supplied from the northern Antarctic Peninsula to the southwest.

2. An upper Quaternary sediment sequence from site PS1565 comprises an interglacial clay mineral assemblage with high smectite amounts and a glacial assemblage characterized by enhanced chlorite concentrations. During glacial periods, chloriteenriched detritus was supplied to the continental rise by gravitational downslope processes triggered by the advance of grounded ice streams to the shelf break.

3. Upper Miocene to Quaternary sediments recovered at continental rise Sites 1095 and 1096 exhibit clay mineral fluctuations alternating between two end-member assemblages. One assemblage is characterized by $<20 \%$ smectite and $>40 \%$ chlorite. The other assemblage has $>20 \%$ smectite and $<40 \%$ chlorite. The clay mineral fluctuations are similar to those observed at site PS1565. We ascribe the short-term changes in clay mineral composition at Sites 1095 and 1096 to repeated ice advances and retreats across the shelf west of the Antarctic Peninsula, reflecting glacial-interglacial cyclicity. We conclude that oscillations in Antarctic ice volume may have influenced the global climate already during the late Miocene.

4. Only slight long-term changes are observed in the clay mineral assemblages deposited at ODP Sites 1095 and 1096. A slight enhancement of smectite contents between $\sim 7.0$ and $\sim 5.4 \mathrm{Ma}$ at Site 1095 may be a consequence of a higher smectite supply caused by an intensification of volcanism in the northern Antarctic Peninsula region and by a strengthening of glacial erosion 
C.-D. Hillenbrand And W. Ehrmann

Distribution of Clay Minerals in DRIFt Sediments

16

in northern Graham Land in response to local uplift associated with ridge crest-trench collision. An increase of elite at Site 1096 between $\sim 1.5$ and $\sim 0.2 \mathrm{Ma}$ is probably caused by changes in the supply of glacial debris from different source areas on the southen Antarctic Peninsula. The clay mineral assemblages deposited at Drift 7 point to an onset of vast glaciation in the Antarctic Peninsula region before 9 Ma but give no evidence for major deglaciation events since then.

ACKNOWLEDGMENTS

We thank the crew and the Shipboard Scientific Party of Leg 178 for taking samples for us and making this study possible. We wish to thank H. Grove, H. Rhodes, and M. Seebeck for supporting our laboratory work. Our paper benefited from constructive criticism by our colleagues B. Diekmann, C. Pudsey, D. Fütterer, and T. Wolf-Welling. Furthermore, we thank A. Camerlenghi, C. Robert, and M. Sett for their helpful reviews of the manuscript. We gratefully acknowledge financial support from the Deutsche Forschungsgemeinschaft. 


\section{REFERENCES}

Abreu, V.S., and Anderson, J.B., 1998. Glacial eustasy during the Cenozoic: sequence stratigraphic implications. AAPG Bull., 82:1385-1400.

Anderson, J.B., 1990. Sediments. In Glasby, G.P. (Ed.), Antarctic Sector of the Pacific, Elsevier Oceanogr. Ser., 51:187-206.

Ashley, G.M., and Smith, N., 2000. Marine sedimentation at a calving glacier margin. Geol. Soc. Am. Bull., 112:657-667.

Barker, P.F., Barrett, P.J., Camerlenghi, A., Cooper, A.K., Davey, F.J., Domack, E.W., Escutia, C., Kristoffersen, Y., and O'Brien, P.E., 1998. Ice sheet history from Antarctic continental margin sediments: the ANTOSTRAT approach. Terra Antart., 5:737760.

Barker, P.F., Barrett, P.J., Cooper, A.K., and Huybrechts, P., 1999. Antarctic glacial history from numerical models and continental margin sediments. Palaeogeogr., Palaeoclimatol., Palaeoecol., 150:247-267.

Barker, P.F., Camerlenghi, A., Acton, G.D., et al., 1999. Proc. ODP, Init. Repts., 178 [CDROM]. Available from: Ocean Drilling Program, Texas A\&M University, College Station, TX 77845-9547, U.S.A.

Barker, P.F., Kennett, J.P., et al., 1988. Proc. ODP, Init. Repts., 113: College Station, TX (Ocean Drilling Program).

Barrett, P.J. (Ed.), 1986. Antarctic Cenozoic history from the MSSTS-1 drillhole, McMurdo Sound. DSIR Bull. N.Z., 237:1-171.

- (Ed.), 1989. Antarctic Cenozoic history from the CIROS-1 drillhole, McMurdo Sound. DSIR Bull. N.Z., 245:1-254.

Barrett, P.J., and Scientific Staff, 1985. Plio-Pleistocene glacial sequence cored at CIROS-2, Jerrar Fjord, McMurdo Sound. N.Z. Antarct. Rec., 6:8-19.

Barron, J., Larsen, B., et al., 1989. Proc. ODP, Init. Repts., 119: College Station, TX (Ocean Drilling Program).

Bentley, M.J., and Anderson, J.B., 1998. Glacial and marine geological evidence for the ice-sheet configuration in the Weddell Sea-Antarctic Peninsula region during the Last Glacial Maximum. Antarct. Sci., 10:309-325.

Berggren, W.A., Kent, D.V., Swisher, C.C., III, and Aubry, M.-P., 1995. A revised Cenozoic geochronology and chronostratigraphy. In Berggren, W.A., Kent, D.V., Aubry, M.-P., and Hardenbol, J. (Eds.), Geochronology, Time Scales and Global Stratigraphic Correlation. Spec. Publ.-Soc. Econ. Paleontol. Mineral. (Soc. Sediment. Geol.), 54:129-212.

Biscaye, P.E., 1964. Distinction between kaolinite and chlorite in recent sediments by X-ray diffraction. Am. Miner., 49:1281-1289.

- 1965 . Mineralogy and sedimentation of recent deep-sea clays in the Atlantic Ocean and adjacent seas and oceans. Geol. Soc. Am. Bull., 76:803-832.

Blümel, W.D., Emmermann, R., and Smykatz-Kloss, W., 1985. Vorkommen und Entstehung von tri-oktaedrischen Smektiten in den Basalten und Böden der KönigGeorg-Insel (S-Shetlands/West-Antarktis). Polarforschung, 55:33-48.

Brindley, G.W., and Brown, G. (Eds.), 1980. Crystal Structures of Clay Minerals and Their X-ray Identification. Mineral. Soc. London Monogr., 5.

Camerlenghi, A., Crise, A., Pudsey, C.J., Accerboni, E., Laterza, R., and Rebesco, M., 1997. Ten-month observation of the bottom current regime across a sediment drift of the Pacific margin of the Antarctic Peninsula. Antarct. Sci., 9:426-433.

Cape Roberts Science Team (CRST), 1998. Initial report on CRP-1. Terra Antart., 5.

- 1999. Studies from the Cape Roberts Project, Ross Sea, Antarctica-Initial report on CRP-2/2A. Terra Antart., 6(1/2).

- 2000. Studies from the Cape Roberts Project, Ross Sea, Antarctica: Initial report on CRP-3. Terra Antart., 7.

Care, B.W., 1983. The petrology of the Rouen Mountains, northern Alexander Island. Brit. Antarct. Surv. Bull., 52:63-86. 
Chamley, H., 1989. Clay Sedimentology: Berlin (Springer-Verlag).

Davey, F.J., 1990. Structure and tectonics. In Glasby, G.P. (Ed.), Antarctic Sector of the Pacific, Elsevier Oceanogr. Ser., 51:125-154.

Davies, T.G., 1984. The geology of part of northern Palmer Land. Brit. Antarct. Surv. Sci. Rep., 103:46 pp.

Diekmann, B., Kuhn, G., Rachold, V., Abelmann, A., Brathauer, U., Fütterer, D.K., Gersonde, R., Grobe, H., 2000. Terrigenous sediment supply in the Scotia Sea (Southern Ocean): Response to Late Quaternary ice dynamics in Patagonia and on the Antarctic Peninsula. Palaeogeogr., Palaeoclimatol., Palaeoecol., 162:357-387.

Diekmann, B., Petschick, R., Gingele, F.X., Fütterer, D.K., Abelmann, A., Brathauer, U., Gersonde, R., and Mackensen, A., 1996. Clay mineral fluctuations in Late Quaternary sediments of the southeastern South Atlantic: implications for past changes of deep water advection. In Wefer, G., Berger, W.H., Siedler, G., and Webb, D.J. (Eds.), The South Atlantic: Present and Past Circulation: Berlin-Heidelberg (Springer), 621-644.

Dingle, R.V., and Lavelle, M., 1998. Late Cretaceous-Cenozoic climatic variations of the northern Antarctic Peninsula: new geochemical evidence and review. Palaeogeogr., Palaeoclimatol., Palaeoecol., 141:215-232.

Domack, E.W., and Ishman, S., 1993. Oceanographic and physiographic controls on modern sedimentation within Antarctic fjords. Geol. Soc. Am. Bull., 105:11751189.

Ehrmann, W., 1998a. Implications of late Eocene to early Miocene clay mineral assemblages in McMurdo Sound (Ross Sea, Antarctica) on paleoclimate and ice dynamics. Palaeogeogr., Palaeoclimatol., Palaeoecol., 139:213-231.

— 1998b: Lower Miocene and Quaternary clay mineral assemblages from CRP1. Terra Antart., 5:613-619.

- in press. Smectite content and crystallinity in sediments from CRP-2/2a, Ross Sea, Antarctica. Terra Antart.

Ehrmann, W.U., and Mackensen, A., 1992. Sedimentological evidence for the formation of an East Antarctic ice sheet in Eocene/Oligocene time. Palaeogeogr., Palaeoclimatol., Palaeoecol., 93:85-112.

Ehrmann, W.U., Melles, M., Kuhn, G., and Grobe, H., 1992. Significance of clay mineral assemblages in the Antarctic Ocean. Mar. Geol., 107:249-273.

Elliot, D.H., 1997. The planar crest of Graham Land, northern Antarctic Peninsula: possible origins and timing of uplift. In Barker, P.F., and Cooper, A.K. (Eds.), Geology and Seismic Stratigraphy of the Antarctic Margin (Pt 2). Am. Geophys. Union, Antarct. Res. Ser., 71:51-73.

Hambrey, M.J., Ehrmann, W.U., and Larsen, B., 1991. Cenozoic glacial record of the Prydz Bay continental shelf, East Antarctica. In Barron, J., Larsen, B., et al., Proc. ODP, Sci. Results, 119: College Station, TX (Ocean Drilling Program), 77-132.

Hillenbrand, C.-D., 2000. Glaciomarine sedimentation on the continental margins of the Amundsen and Bellingshausen Seas, West Antarctica-indications for paleoenvironmental changes during the Quaternary climatic cycles. Rep. Polar Res., 346: Bremerhaven (Alfred Wegener Institute for Polar and Marine Research).

Hodell, D.A., Benson, R.H., Kent, D.V., Boersma, A., and Rakic-El Bied, K., 1994. Magnetostratigraphic, biostratigraphic, and stable isotope stratigraphy of an Upper Miocene drill core from the Salé Briqueterie (northwestern Morocco): a high-resolution chronology for the Messinian stage. Paleoceanography, 9:835-855.

Hoecker, G., and Amstutz, G.C., 1987. Petrographie der mesozoischen Magmatite im Gebiet des Palmer Archipels (Antarktische Halbinsel) unter besonderer Berücksichtigung von geochemisch-lagerstättenkundlichen Gesichtspunkten. Polarforschung, 57:43-57.

Hofmann, E.E., Klinck, J.M., Lascara, C.M., and Smith, D.A., 1996. Water mass distribution and circulation west of the Antarctic Peninsula and Bransfield Strait. Antarct. Res. Ser., 70:61-80. 
Hollister, C.D., Craddock, C., et al., 1976. Init. Repts. DSDP, 35: Washington (U.S. Govt. Printing Office).

Jeffers, J.D., and Anderson, J.B., 1990. Sequence stratigraphy of the Bransfield Basin, Antarctica: implications for tectonic history and hydrocarbon potential. In St. John, B. (Ed.), Antarctica as an Exploration Frontier, Hydrocarbon Potential, Geology, and Hazards, Stud. in Geol., 31: Tulsa (American Association of Petroleum Geologists), 13-29.

Kennedy, D.S., and Anderson, J.B., 1989. Glacial-marine sedimentation and Quaternary glacial history of Marguerite Bay, Antarctic Peninsula. Quat. Res., 31:255-276.

Kennett, J.P., and Barker, P.F., 1990. Latest Cretaceous to Cenozoic climate and oceanographic developments in the Weddell Sea, Antarctica: an ocean-drilling perspective. In Barker, P.F., Kennett, J.P., et al., Proc. ODP, Sci. Results, 113: College Station, TX (Ocean Drilling Program), 937-960.

Keys, J.R., 1990. Ice. In Glasby, G.P. (Ed.), Antarctic Sector of the Pacific, Elsevier Oceanogr. Ser., 51:95-123.

Larter, R.D., and Barker, P.F., 1989. Seismic stratigraphy of the Antarctic Peninsula Pacific margin: a record of Pliocene-Pleistocene ice volume and paleoclimate. Geology, 17:731-734.

, 1991. Neogene interaction of tectonic and glacial processes at the Pacific margin of the Antarctic Peninsula. In Macdonald, D.I.M. (Ed.), Sedimentation, Tectonics and Eustasy: Sea-level Changes at Active Margins. Spec. Publ. Int. Assoc. Sedimentol., 12:165-186.

Larter, R.D., and Cunningham, A.P., 1993. The depositional pattern and distribution of glacial-interglacial sequences on the Antarctic Peninsula Pacific Margin. Mar. Geol., 109:203-219.

Larter, R.D., Rebesco, M., Vanneste, L.E., Gamboa, L.A.P., and Barker, P., 1997. Cenozoic tectonic, sedimentary and glacial history of the continental shelf west of Graham Land, Antarctic Peninsula. In Cooper, A.K., Barker, P.F., and Brancolini, G. (Eds.), Geology and Seismic Stratigraphy of the Antarctic Margin (Pt. 2). Antarct. Res. Ser., 71:1-27.

Lear, C.H., Elderfield, H., and Wilson, P.A., 2000. Cenozoic deep-sea temperatures and global ice volumes from $\mathrm{Mg} / \mathrm{Ca}$ in benthic foraminiferal calcite. Science, 287:269272.

Loske, W., Miller, H., and Töpfner, C., 1998. Sedimentary recycling of Palaeozoic granitoids in the Antarctic Peninsula. Terra Antart., 5:201-207.

Macdonald, D.I.M., and Butterworth, P.J., 1990. The stratigraphy, setting and hydrocarbon potential of the Mesozoic sedimentary basins of the Antarctic Peninsula. In St. John, B. (Ed.), Antarctica as an Exploration Frontier, Hydrocarbon Potential, Geology, and Hazards. Stud. in Geol., 31:101-125.

Nowlin, W.D., Jr., and Zenk, W., 1988. Westward bottom currents along the margin of the South Shetland island arc. Deep-Sea Res., 35:269-301.

Orsi, A.H., Nowlin Jr., W.D., and Whitworth III, T., 1993. On the circulation and stratification of the Weddell Gyre. Deep-Sea Res. I, 40:169-203.

Orsi, A.H., Whitworth III, T., and Nowlin Jr., W.D., 1995. On the meridional extent and fronts of the Antarctic Circumpolar Current. Deep-Sea Res. I, 42:641-673.

Parkinson, C.L., 1994. Spatial patterns in the length of the sea ice season in the Southern Ocean, 1979-1986. J. Geophys. Res., 99:16327-16339.

Petschick, R., Kuhn, G., and Gingele, F., 1996. Clay mineral distribution in surface sediments of the South Atlantic: sources, transport, and relation to oceanography. Mar. Geol., 130:203-229.

Piper, D.J.W., and Pe, G.G., 1977. Cenozoic clay mineralogy from D.S.D.P. holes on the continental margin of the Australia-New Zealand sector of Antarctica. N. Z. J. Geol. Geophys., 20:905-917.

Pirrie, D., 1991. Controls on the petrographic evolution of an active margin sedimentary sequence: the Larsen Basin, Antarctica. In Morton, A.C., Todd, S.P., and 
Haughton, P.D.W. (Eds.), Developments in Sedimentary Provenance Studies, Geol. Soc. Spec. Publ. London, 57:231-249.

Pope, P.G., and Anderson, J.B., 1992. Late Quaternary glacial history of the northern Antarctic Peninsula's western continental shelf: evidence from the marine record. In Elliot, D. H. (Ed.), Contributions to Antarctic Research III. Am. Geophys. Union, Antarct. Res. Ser., 57:63-91.

Pudsey, C.J., 2000. Sedimentation on the continental rise west of the Antarctic Peninsula over the last three glacial cycles. Mar. Geol., 167:313-338.

Pudsey, C.J., Barker, P.F., and Larter, R.D., 1994. Ice sheet retreat from the Antarctic Peninsula shelf. Cont. Shelf Res., 14:1647-1675.

Pudsey, C.J., and Camerlenghi, A., 1998. Glacial-interglacial deposition on a sediment drift on the Pacific margin of the Antarctic Peninsula. Antarct. Sci., 10:286308.

Rebesco, M., Camerlenghi, A., and Zanolla, C., 1998. Bathymetry and morphogenesis of the continental margin west of the Antarctic Peninsula. Terra Antart., 5:715-725.

Rebesco, M., Larter, R.D., Barker, P.F., Camerlenghi, A., and Vanneste, L.E., 1997. The history of sedimentation on the continental rise west of the Antarctic Peninsula. In Barker, P.F., and Cooper, A.K. (Eds.), Geology and Seismic Stratigraphy of the Antarctic Margin (Pt. 2). Am. Geophys. Union, Antarctic Res. Ser., 71:29-50.

Rebesco, M., Larter, R.D., Camerlenghi, A., and Barker, P.F., 1996. Giant sediment drifts on the continental rise of the Antarctic Peninsula. Geo-Mar. Lett., 16:65-75.

Robert, C., and Maillot, H., 1983. Paleoenvironmental significance of clay mineralogical and geochemical data, Southwest Atlantic, DSDP Legs 36 and 71. In Ludwig, W.J., Krasheninnikov, V.A., et al., Init. Repts. DSDP, 71: Washington (U.S. Govt. Printing Office), 317-343.

Setti, M., Lopez-Galindo, A., and Ben Aboud, A., 1997. XRD, SEM and TEM investigations of smectites of the Core CIROS-1 (Ross Sea, Antarctica). Terra Antart., 4:119125.

Setti, M., Marinoni, L., Lopez-Galindo, A., and Ben Aboud, A., 1998. TEM observations and rare earth element analysis on the clay minerals of the CRP-1 Core (Ross Sea, Antarctica). Terra Antart., 5:621-626.

Shackleton, N.J., 1995. New data on the evolution of Pliocene climatic variability. In Vrba, E.S., Denton, G.H., Partridge, T.C., and Burckle, L.H. (Eds.). Paleoclimate and evolution with emphasis on human origins: Yale (Yale University Press), 242-248.

Shackleton, N.J., and Crowhurst, S., 1997. Sediment fluxes based on an orbitally tuned time scale $5 \mathrm{Ma}$ to $14 \mathrm{Ma}$, Site 926. In Shackleton, N.J., Curry, W.B., Richter, C., and Bralower, T.J. (Eds.), Proc. ODP, Sci. Results, 154: College Station, TX (Ocean Drilling Program), 69-82.

Shackleton, N.J., and Hall, M.A., 1997. The late Miocene stable isotope record, Site 926. In Shackleton, N.J., Curry, W.B., Richter, C., and Bralower, T.J. (Eds.), Proc. ODP, Sci. Results, 154: College Station, TX (Ocean Drilling Program), 367-373.

Shuitu, G., 1990. Clay minerals in the northwestern sea area of the Antarctic Peninsula. Antarct. Res., 2:35-42.

Smellie, J.L., 1990. Graham Land and South Shetland Islands. In LeMasurier, W.E., and Thomson, J.W. (Eds.), Volcanoes of the Antarctic Plate and Southern Oceans, Antarct. Res. Ser., 48:303-312.

, 1999. Lithostratigraphy of Miocene-Recent, alkaline volcanic fields in the Antarctic Peninsula and eastern Ellsworth Land. Antarct. Sci., 11:362-378.

Smellie, J.L., and Skilling, I.P., 1994. Products of subglacial volcanic eruptions under different ice thicknesses: two examples from Antarctica. Sediment. Geol., 91:115129.

Smith, C.G., 1987. The geology of parts of the west coast of Palmer Land. Brit. Antarct. Surv. Sci. Rep., 112.

Smith, D.A., Hofmann, E.E., Klinck, J.M., and Lascara, C.M., 1999. Hydrography and circulation of the West Antarctic Peninsula Shelf. Deep-Sea Res. I, 46:925-949. 
Talbot, M.H., 1988. Oceanic environment of George VI ice shelf, Antarctic Peninsula. Ann. Glaciol., 11:161-164.

Thomson, M.R.A., and Pankhurst, R.J., 1983. Age of Post-Gondwanian calc-alkaline volcanism in the Antarctic Peninsula region. In Oliver, R.L., James, P.R., and Jago, J.B. (Eds.), Antarctic Earth Science: Cambridge (Cambridge University Press) 328333.

Thomson, M.R.A., Pankhurst, R.J., and Clarkson, P.D., 1983. The Antarctic Peninsula-a late Mesozoic-Cenozoic arc (review). In Oliver, R.L., James, P.R., and Jago, J.B. (Eds.), Antarctic Earth Science: Cambridge (Cambridge University Press) 289294.

Tomlinson, J.S., Pudsey, C.J., Livermore, R.A., Larter, R.D., and Barker, P.F., 1992. GLORIA survey of the Pacific margin of the Antarctic Peninsula: tectonic fabric and sedimentary processes. In Yoshida, Y., Kaminuma, K., and Shiraishi, K. (Eds.), Recent Progress in Antarctic Earth Science: Tokyo (Terra Sci. Publ.), 423-429.

Tucholke, B.E., 1977. Sedimentation processes and acoustic stratigraphy in the Bellingshausen Basin. Mar. Geol., 25:209-230.

Vanneste, L.E., and Larter, R.D., 1995. Deep-tow boomer survey on the Antarctic Peninsula Pacific margin: an investigation of the morphology and acoustic characteristics of Late Quaternary sedimentary deposits on the outer continental shelf and upper slope. In Cooper, A.K., Barker, P.F., and Brancolini, G. (Eds.), Geology and Seismic Stratigraphy of the Antarctic Margin. Am. Geophys. Union, Antarct. Res. Ser., 68:97-121.

Vanney, J.R., and Johnson, G.L., 1976. The Bellingshausen-Amundsen Basins (southeastern Pacific): major sea-floor units and problems. Mar. Geol., 22:71-101.

Weaver, C.E., 1989. Clays, Muds, and Shales: New York (Elsevier), Dev. in Sedimentol. Ser., 44.

Webb, P.-N., and Harwood, D.M., 1991. Late Cenozoic glacial history of the Ross Embayment, Antarctica. In Cronin, T.M., and Dowsett, H.J. (Eds.), Pliocene Climates. Quat. Sci. Rev., 10:215-223.

West, S.M., 1974. The geology of the Danco Coast, Graham Land. Brit. Antarct. Surv. Sci. Rep., 84.

Whitworth III, T., Orsi, A.H., Kim, S.-J., Nowlin Jr., W.D., and Locarnini, R.A., 1998. Water masses and mixing near the Antarctic Slope Front. In Jacobs, S., and Weiss, R. (Eds.), Ocean, Ice, and Atmosphere: Interactions at the Antarctic Continental Margin, Antarct. Res. Ser., 75:1-27.

Wright, R., Anderson, J.B., and Fisco, P.P., 1983. Distribution and association of sediment gravity flow deposits and glacial/glacial-marine sediments around the continental margin of Antarctica. In Molnia, B. F. (Ed.), Glacial-Marine Sedimentation: New York (Plenum), 265-300.

Yoon, H.I., Han, M.W., Park, B.K., Han, S.J., and Oh, J.K., 1992. Distribution, provenance, and dispersal pattern of clay minerals in surface sediments, Bransfield Strait, Antarctica. Geo-Mar. Lett., 12:223-227. 


\section{C.-D. Hillenbrand AND W. Ehrmann

Figure F1. Bathymetric map of the continental margin west of the Antarctic Peninsula (Rebesco et al., 1998) with locations of Sites 1095, 1096, and 1097 (solid circles) and of gravity core PS1565 (cross). SM = seamount, $\mathrm{MSH}=$ midshelf high .

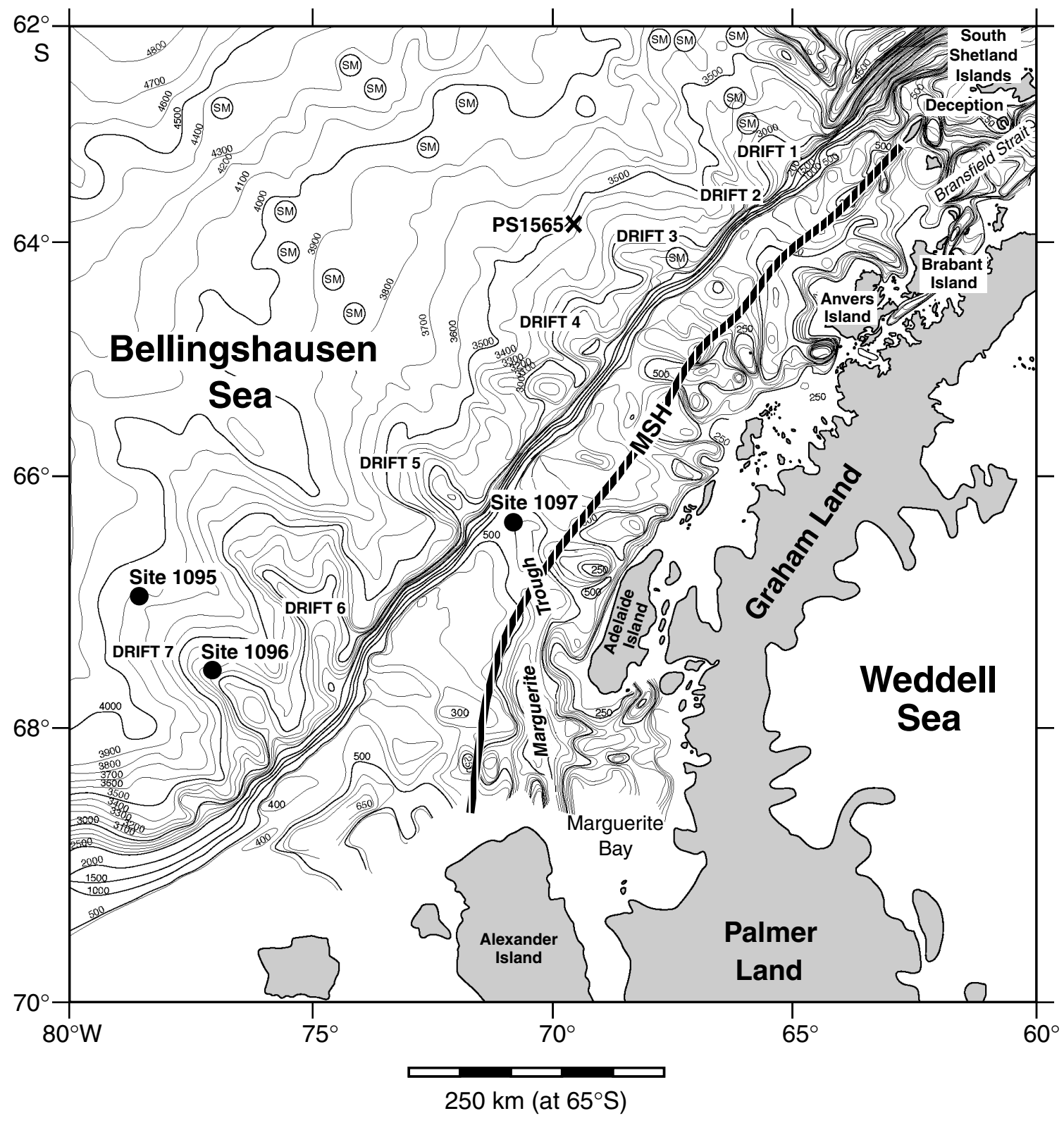


C.-D. Hillenbrand AND W. Ehrmann

Distribution of Clay Minerals in Drift Sediments

Figure F2. Percent distribution of the main clay mineral groups smectite, illite, and chlorite in sediments recovered at Site 1095 plotted against composite depth.

Site 1095

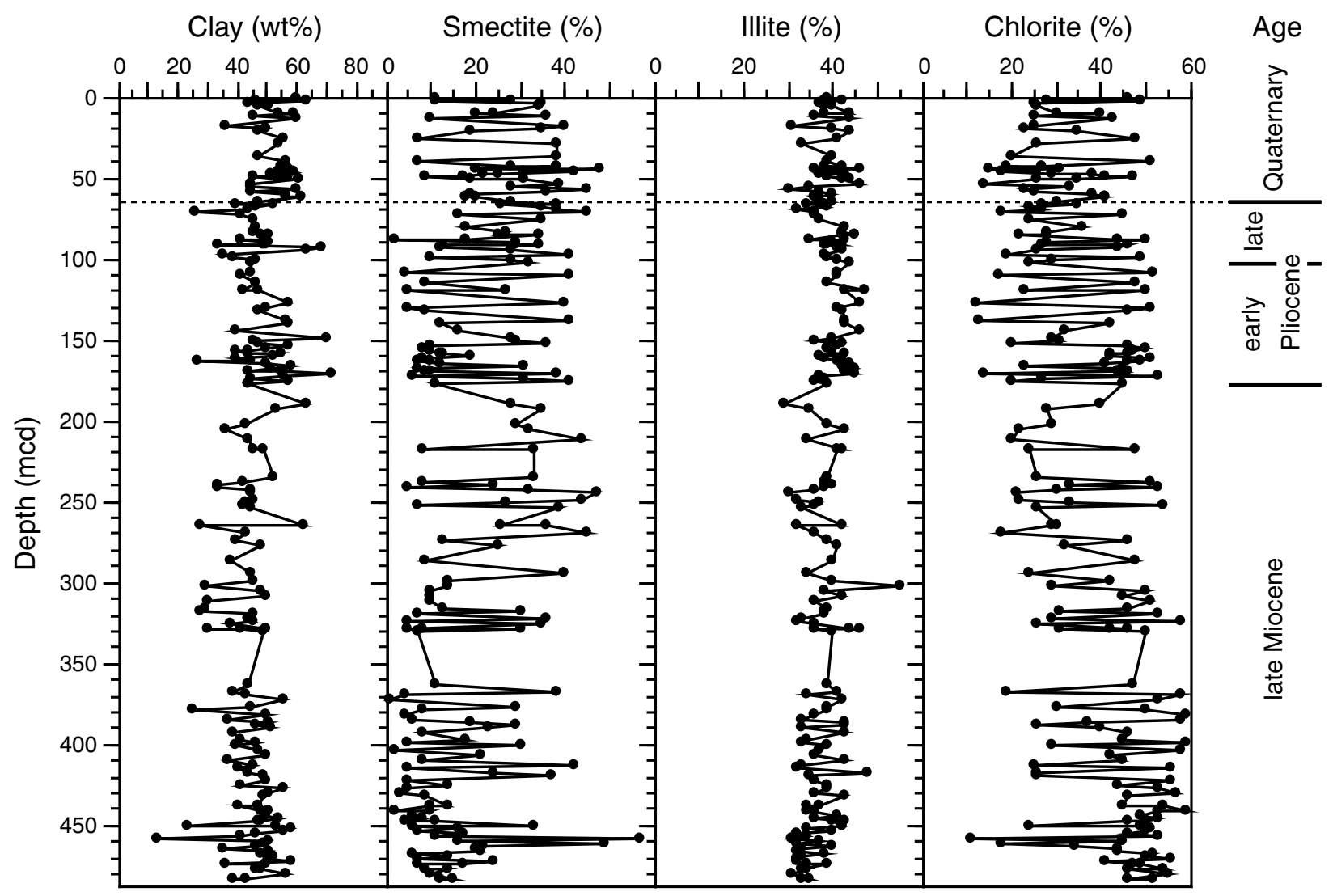


C.-D. Hillenbrand AND W. Ehrmann

Distribution of Clay Minerals in Drift SEDiments

Figure F3. Percent distribution of the main clay mineral groups smectite, illite, and chlorite in sediments recovered at Site 1096 plotted against composite depth.

\section{Site 1096}

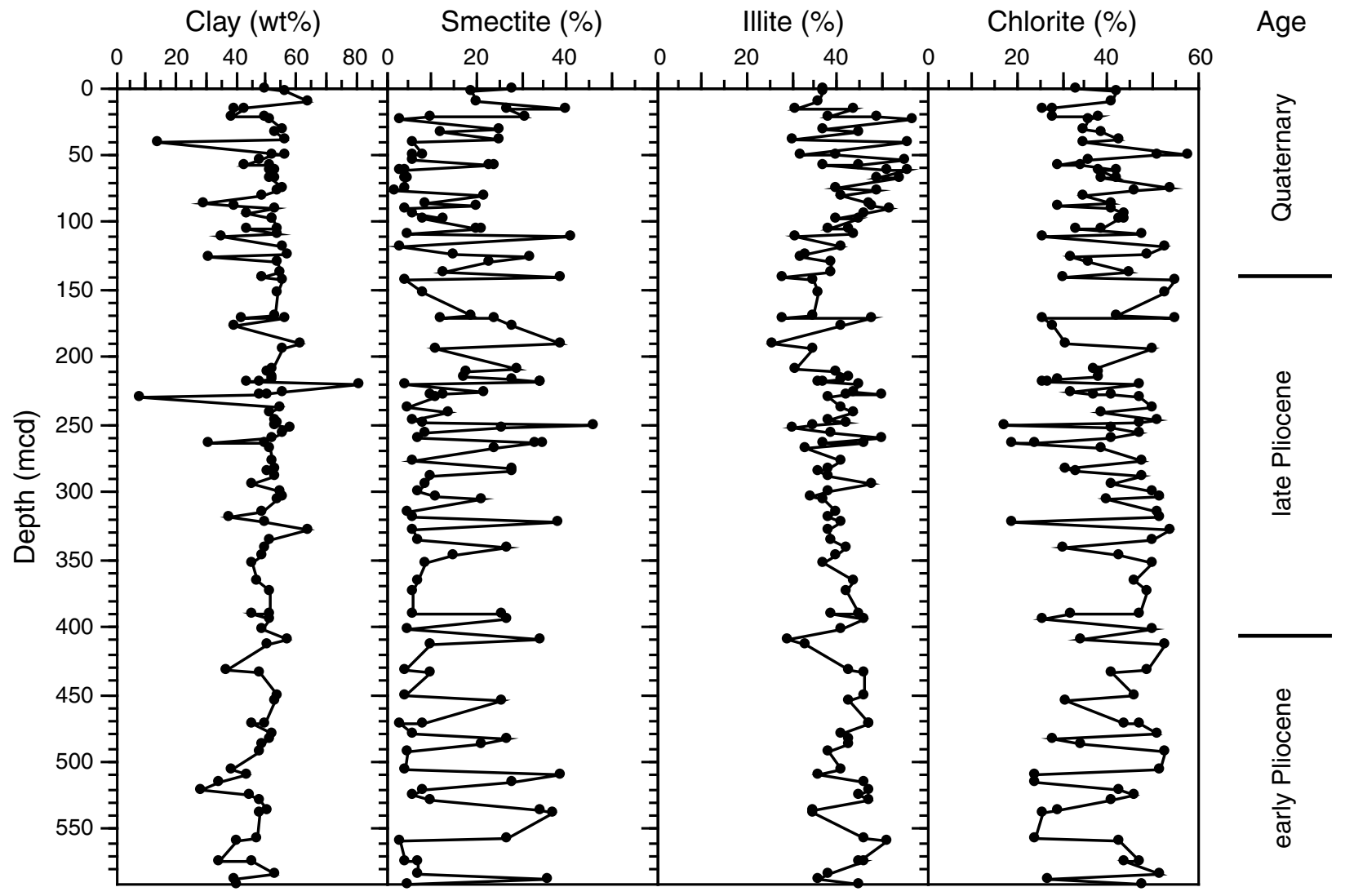




\section{C.-D. Hillenbrand AND W. Ehrmann

Figure F4. Clay mineral assemblages in surface sediments west of the Antarctic Peninsula based on data by Petschick et al. (1996) and Diekmann et al. (2000). For Site 1096 and gravity core PS1565, the clay mineral assemblages of the uppermost core sediments (0-1 cm below seafloor) are also shown. For Site 1097, the mean clay mineral composition of all investigated samples is given. The clay mineral assemblage on the shelf in the northeast is characterized by high smectite contents (smectite province), whereas shelf sediments farther in the southwest contain more chlorite and illite (chlorite-illite province). Surface sediments at the continental rise offshore from the chlorite-illite province are characterized by enhanced smectite contents in respect to the deposits on the adjacent shelf.

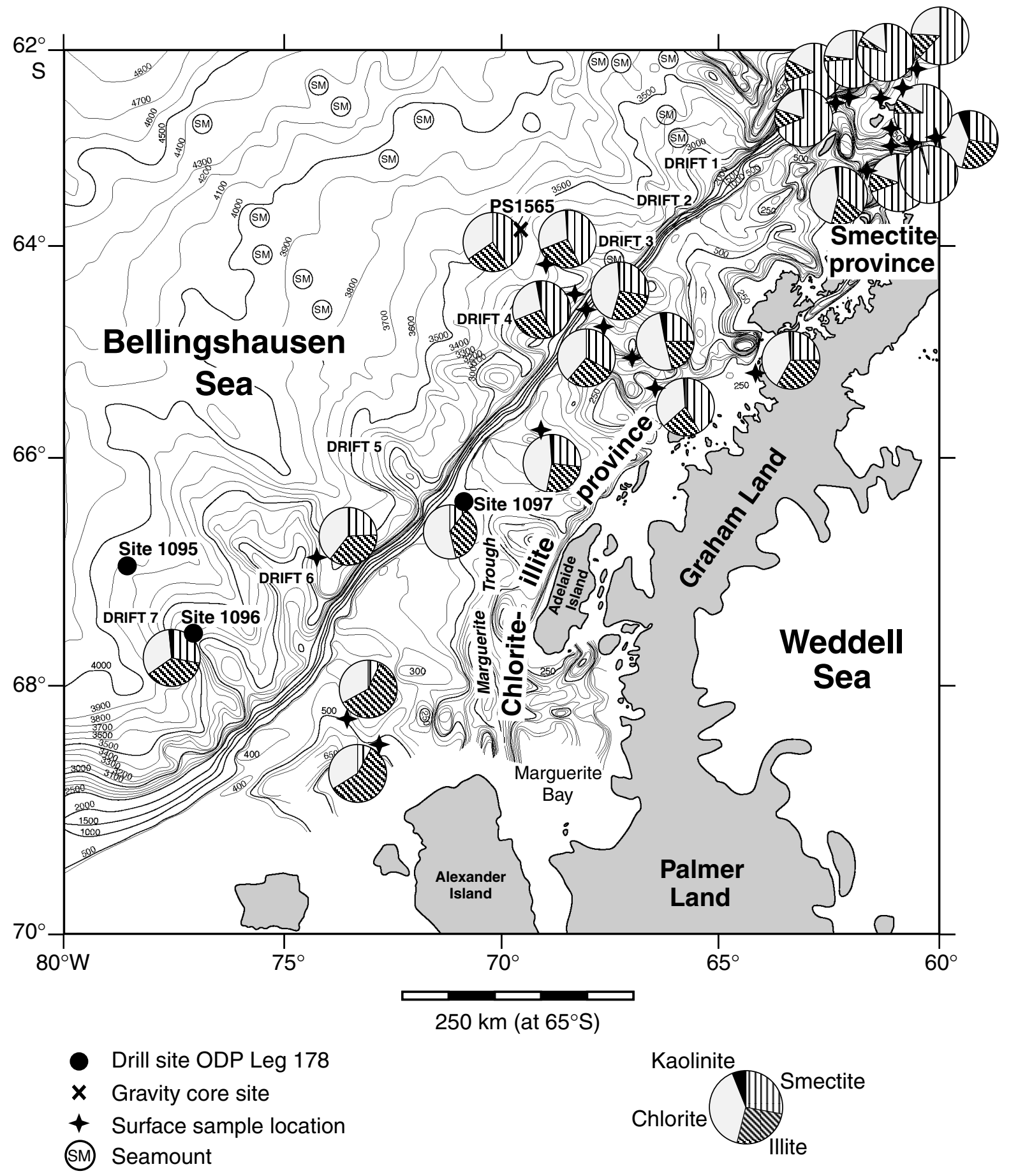




\section{C.-D. Hillenbrand AND W. Ehrmann}

Figure F5. Clay content and contents of smectite, illite, and chlorite in upper Quaternary sediments of gravity core PS1565 (Hillenbrand, 2000). Smectite contents exhibit maxima during the interglacial oxygen isotope Stages 5 and 1, and chlorite concentrations are highest during glacial Stages 6 and 4-2. Clay and illite contents show no significant trends.

\section{PS1565}

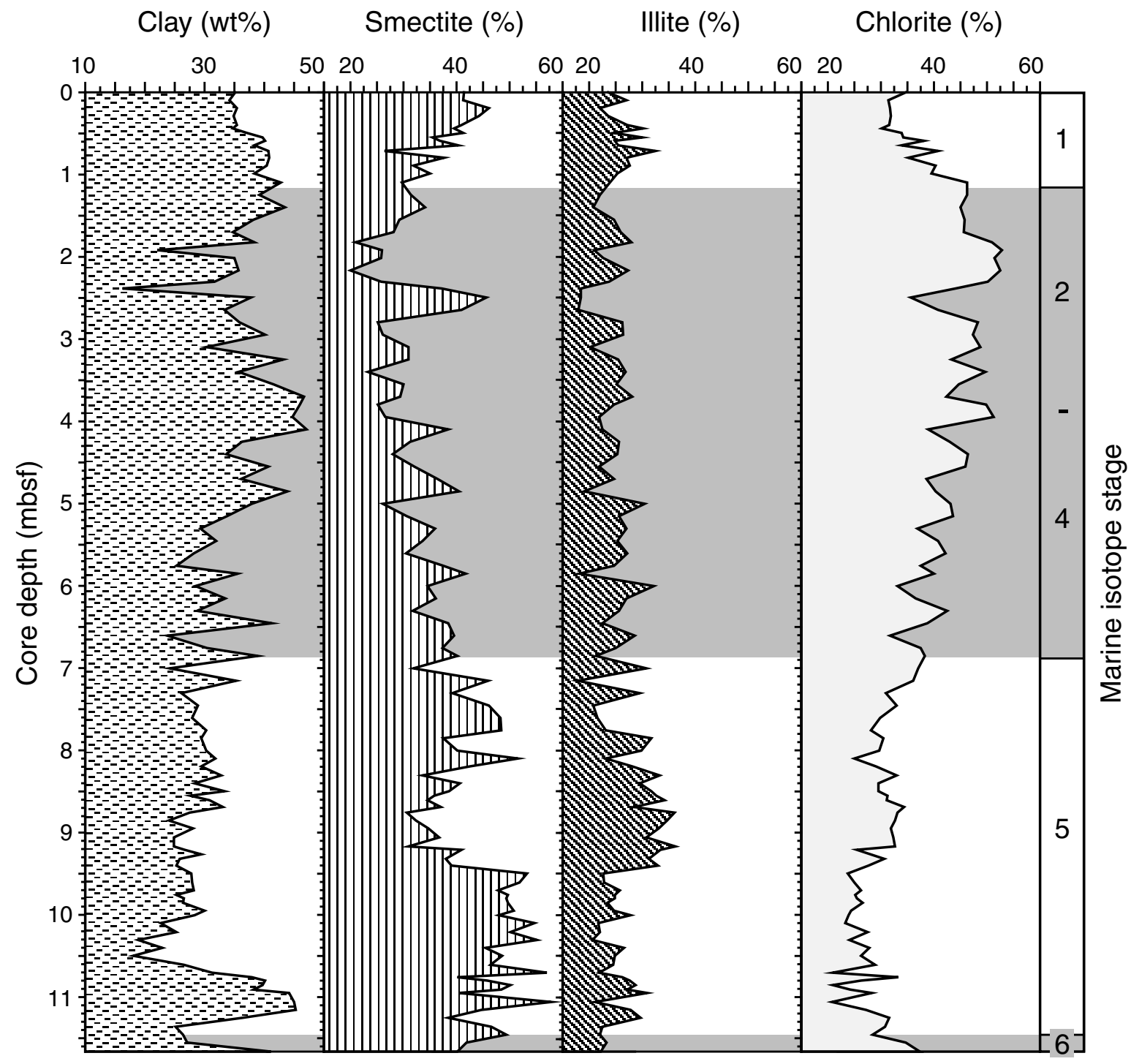


C.-D. Hillenbrand AND W. Ehrmann

Distribution of Clay Minerals in Drift Sediments

Figure F6. Temporal variations in the clay mineral composition of sediments from (A) Site 1095 and (B) Site 1096.

A

Site 1095

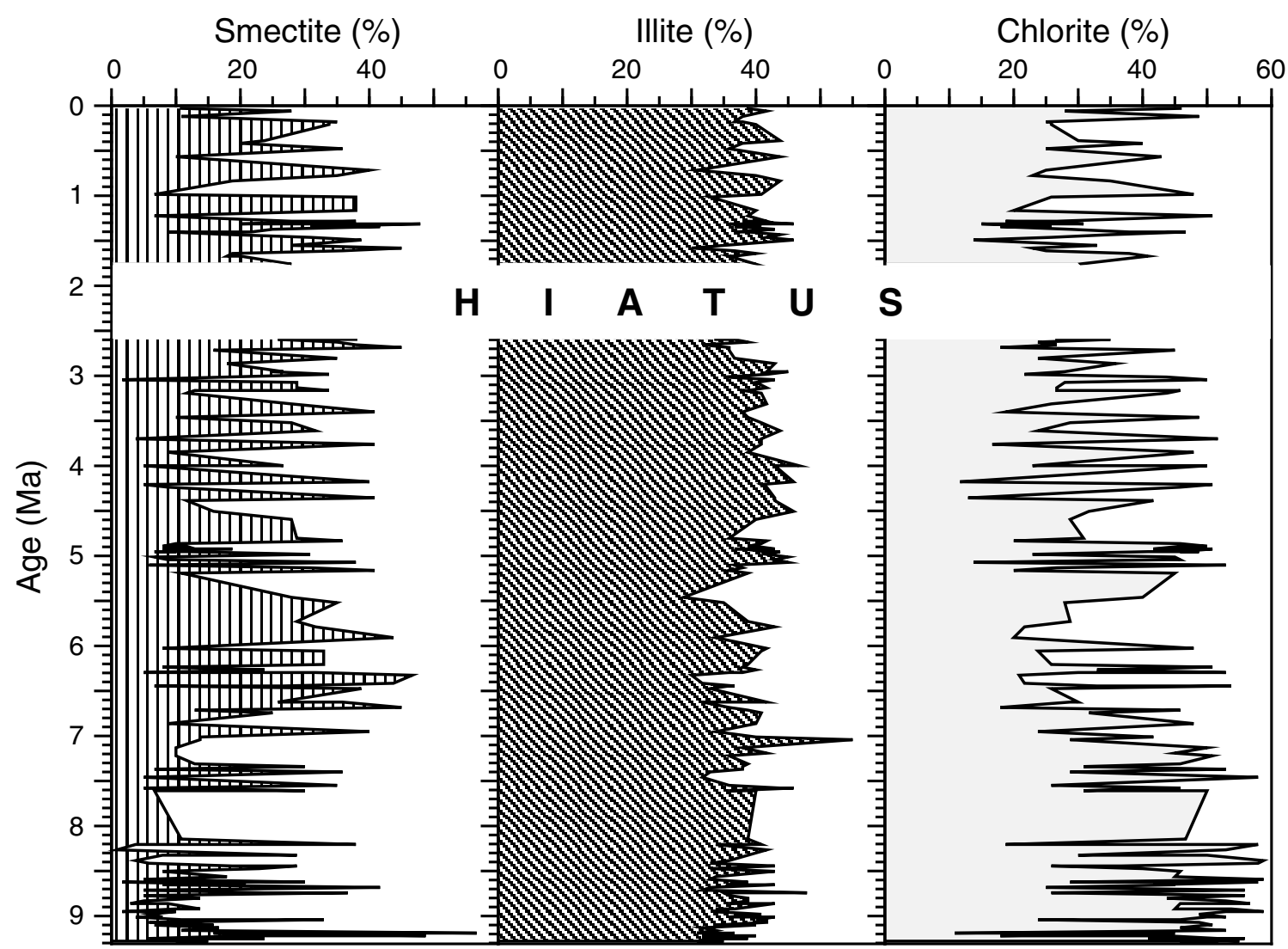

B

Site 1096

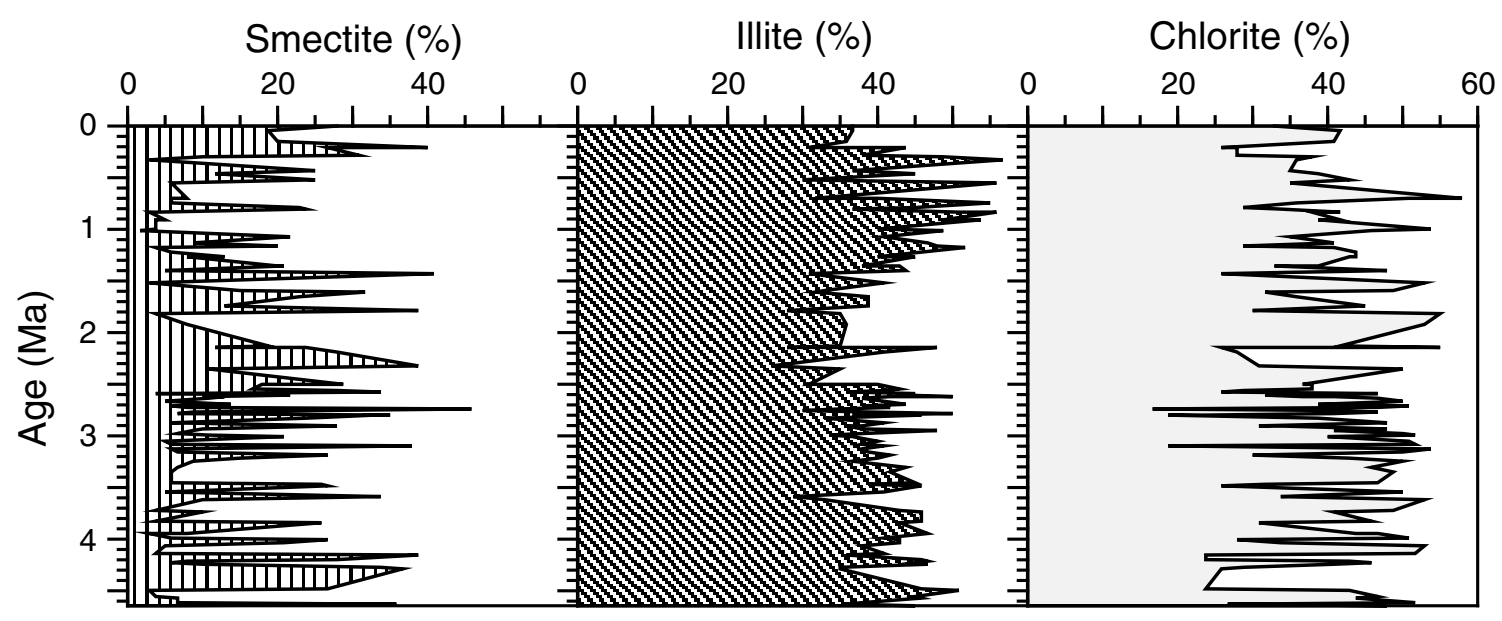




\section{C.-D. Hillenbrand and W. Ehrmann

Figure F7. Ternary plot of the clay mineral composition of the 192 investigated samples from Site 1095 and the 119 investigated samples from Site 1096. Kaolinite occurs only in trace amounts and was added to the chlorite content. Clay mineral fluctuations at Sites 1095 and 1096 alternate between two end-member assemblages. One assemblage is characterized by $<20 \%$ smectite and $>40 \%$ chlorite. The second assemblage has $>20 \%$ smectite and $<40 \%$ chlorite.

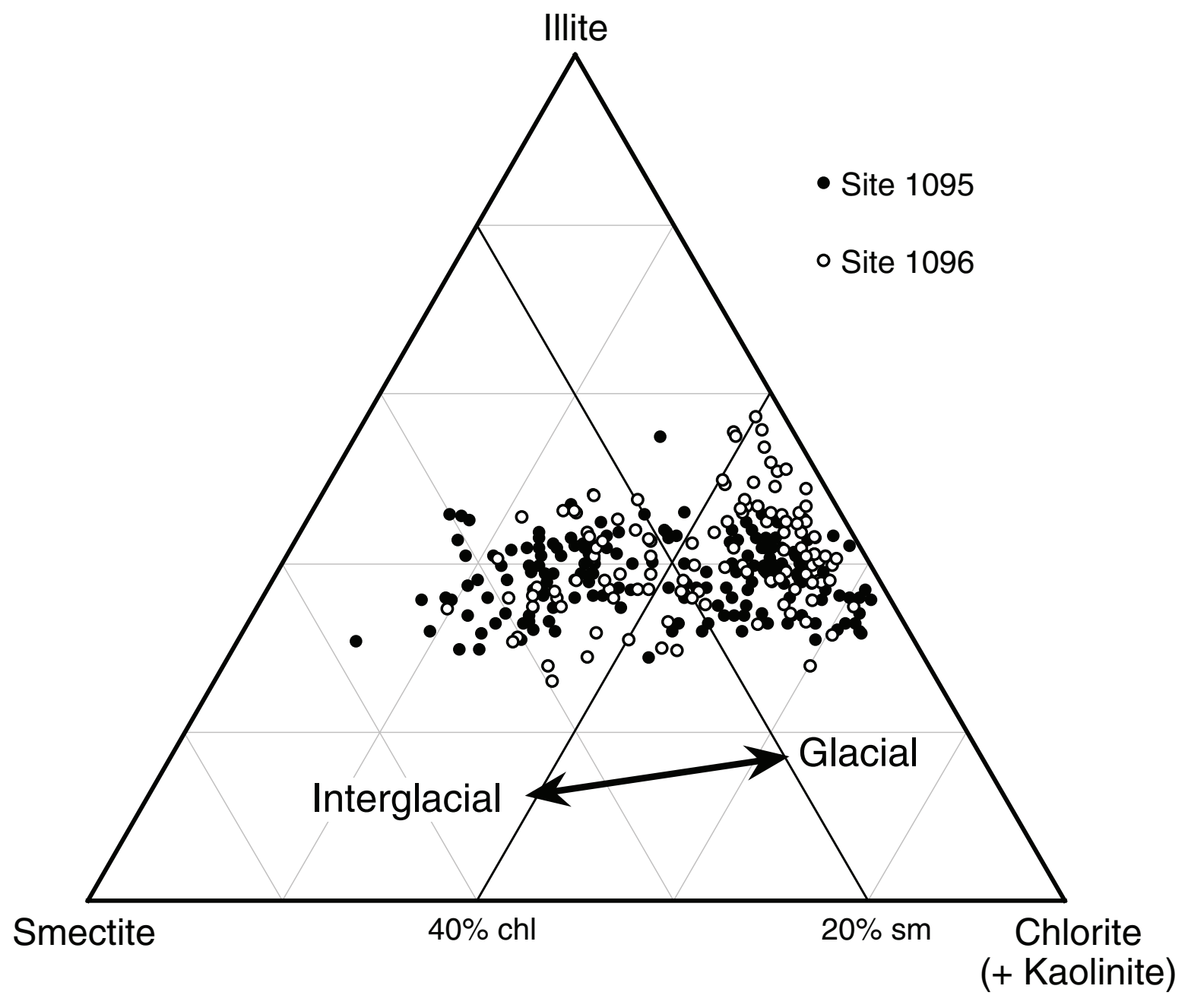




\section{C.-D. Hillenbrand AND W. EhrmanN}

Distribution of Clay Minerals in Drift SEDiments

Table T1. Location, water depth, and core recovery, Sites 1095, 1096, and 1097.

\begin{tabular}{ccccccc}
\hline Hole & Latitude & Longitude & $\begin{array}{c}\text { Water } \\
\text { depth }(\mathrm{m})\end{array}$ & $\begin{array}{c}\text { Core } \\
\text { recovery }(\mathrm{m})\end{array}$ & Age & $\begin{array}{c}\text { Number } \\
\text { of samples }\end{array}$ \\
\hline $\begin{array}{c}1095 \mathrm{~A} \\
1095 \mathrm{~B}\end{array}$ & $66^{\circ} 59.1^{\prime} \mathrm{S}$ & $78^{\circ} 29.3^{\prime} \mathrm{W}$ & 3853 & 554.06 & late Miocene-Quaternary & 192 \\
$1096 \mathrm{~A}$ & $67^{\circ} 34.0^{\prime} \mathrm{S}$ & $76^{\circ} 57.8^{\prime} \mathrm{W}$ & 3164 & 673.27 & early Pliocene-Quaternary & 119 \\
$1096 \mathrm{~B}$ & & & & & & \\
$1096 \mathrm{C}$ & & & & & & \\
$1097 \mathrm{~A}$ & $66^{\circ} 23.6^{\prime} \mathrm{S}$ & $70^{\circ} 45.4^{\prime} \mathrm{W}$ & 563 & 59.30 & early Pliocene-?Quaternary & 20 \\
\hline
\end{tabular}

